\title{
NAUKA NA USLUGACH POLITYKI? PRZYPADEK JÓZEFA OBRĘBSKIEGO
}

\author{
Jasną jest przecie rzeczą, \\ że inne sprawdziany i kryteria obowiązują świat nauki, \\ a inne cyrkulują w różnych kręgach politycznych, \\ w których kierunki i teorie naukowe mierzy się najczęściej \\ nie obiektywizmem naukowym i wartością poznawczą, \\ ale przydatnością propagandową i potencjałem mitotwórczym.
}

Józef Obrębski

\section{RESEARCH IN THE SERVICE OF POLITICS? \\ THE CASE OF JÓZEF OBRĘBSKI}

\section{Abstract}

The paper concentrates on the circumstances of the production of anthropological knowledge, created in a dynamic tension between its cognitive goal and the way it is used for political purposes. It provides an insight into a complex network of conditions (intelectual, institutional, financial, personal, political) which determined the production of knowledge in interwar Poland within the then emerging disciplines of ethnology and sociology, in the scope of what today we would call social anthropology.

This case study takes a closer look at Polish anthropologist Józef Obrębski (1905-1967), a close student of Malinowski, whose outstanding achievements remained mostly unpublished and thus never came into existence in the master narrative of the history of our discipline. In the 1930s Obrębski conducted ethnosociological field research in the Polesie region

ANNA ENGELKING

Instytut Slawistyki Polskiej Akademii Nauk, Warszawa

E-mail: engelking@ispan.waw.pl http://orcid.org/0000-0003-3225-8084

CITATION: Engelking, A. (2019). Nauka na usługach polityki? Przypadek Józefa Obrębskiego. Sprawy Narodowościowe. Seria nowa, 2019(51). https://doi.org/10.11649/sn.1863

This work was supported by the author's own resources.

1 (Obrębski, 1939, s. 359). No competing interests have been declared.

This is an Open Access article distributed under the terms of the Creative Commons Attribution 3.0 PL License (creativecommons.org/licenses/by/3.0/pl/), which permits redistribution, commercial and non-commercial, provided that the article is properly cited. (C) The Author(s) 2019

Publisher: Institute of Slavic Studies, Polish Academy of Sciences 
in eastern Poland (nowadays, part of Belarus and Ukraine), which was part of a large scale scientific project of the Commission for Scientific Research of the Eastern Territories. This project, financed by the Polish government and headed by a politician, general Kasprzycki, was supposed to be an efficient tool in the politics of the so called state and national assimilation of the Slavic-speaking ethnic minorities. Obrębski's political views, which were democratic and liberal in character, were opposed to the official political line whereas his functionalist anthropological stance was unacceptable for the mainstream Polish ethnology of the era, still rooted in the positivist paradigm.

Anthropological knowledge produced by Obrębski, which we would call today a postcolonial and constructivist approach, began to find recognition only after his death. The biography of this scholar and the story of his "unknown" work, a great example of a non-mainstream phenomenon in a provincial country, makes it easier to reveal undisclosed mechanisms of the system and the thoughtcollectives of science.

Key words: Józef Obrębski; Bronisław Malinowski; Polesie; functionalism; ethnosociology; fieldwork; history of anthropology; science policy

Streszczenie

Artykuł dotyczy uwarunkowań produkcji wiedzy antropologicznej w dynamicznym napięciu między jej celem poznawczym a zastosowaniem do celów politycznych. Przynosi wgląd w złożoną sieć uwarunkowań (intelektualnych, instytucjonalnych, finansowych, personalnych, politycznych) produkcji wiedzy w międzywojennej Polsce, na polu młodych dyscyplin, jakimi były wówczas etnologia i socjologia, polu, które dzisiaj nazywamy antropologią społeczno-kulturową.

Bohaterem tego studium przypadku jest polski antropolog Józef Obrębski (1905-1967), bliski uczeń Malinowskiego, którego wybitne prace w większości pozostały nieopublikowane, nie funkcjonują zatem w wielkiej opowieści o historii dyscypliny. W latach 1930. Obrębski prowadził etnosocjologiczne badania terenowe na Polesiu we wschodniej Polsce (region ten dziś należy do Białorusi i Ukrainy), w ramach wdrażanego tam na szeroką skalę programu naukowego Komisji Naukowych Badań Ziem Wschodnich. Projekt ten, finansowany przez polski rząd i kierowany przez polityka, gen. Kasprzyckiego, miał być skutecznym narzędziem polityki asymilacji państwowej i narodowej słowiańskojęzycznych mniejszości etnicznych. Demokratyczne i liberalne poglądy polityczne Obrębskiego były opozycyjne wobec linii politycznej jego mocodawców, zaś stanowisko teoretyczno-metodologiczne, związane z funkcjonalizmem, było z kolei nie do przyjęcia przez polskich etnologów głównego nurtu, przywiązanych do paradygmatu pozytywistycznego.

Antropologiczne osiągnięcia Obrębskiego, które dziś sytuujemy w obrębie podejścia postkolonialnego i konstruktywistycznego, zaczęły zyskiwać uznanie dopiero po jego śmierci. Biografia uczonego i dzieje jego "nieznanych" prac, ważny przykład pozamainstreamowego fenomenu w prowincjonalnym kraju, przyczyniają się do poznania nieujawnionych mechanizmów systemu i kolektywów myślowych w nauce.

Słowa kluczowe: Józef Obrębski; Bronisław Malinowski; Polesie; funkcjonalizm; etnosocjologia; badania terenowe; historia antropologii; polityka naukowa

\section{WPROWADZENIE}

W

iedza naukowa produkowana jest zarówno w ścisłym powiązaniu z przedmiotem badań, koncepcjami teoretycznymi i stylem myślowym epoki, jak i w dynamicznej sieci współzależności personalnych, instytucjonalnych, finansowych i politycznych. Autonomia uczonego podlega zatem różnego rodzaju ograniczeniom nie 
tylko natury subiektywnej, lecz także obiektywnej - systemowej. Studium przypadku Józefa Obrębskiego - antropologa-terenowca, prekursora studiów postkolonialnych i zorientowanych nieesencjalistycznie (relacjonalnie) badań nad etnicznością - daje wgląd $w$ tę złożoną sieć uwarunkowań produkcji wiedzy w międzywojennej Polsce, w polu młodych dyscyplin, jakimi były wówczas etnologia i socjologia, polu, które dzisiaj nazywamy antropologią społeczno-kulturową ${ }^{2}$.

Celem tego artykułu jest właśnie dokonanie takiego wglądu. Chcę się w nim przyjrzeć, na przykładzie konkretnego uczonego, formatującemu badania naukowe splotowi czynników indywidualnych (jakimi są fakty biograficzne, motywacje, postawy) i niezależnych od jednostki, zwłaszcza tych pochodzących z obszaru polityki państwa i jego organów. Swoista mikrohistoria kontekstu rozpoczętych przez Obrębskiego wiosną 1934 roku badań etnosocjologicznych na Polesiu ${ }^{3}$ - w regionie usytuowanym w administracyjnych granicach ówczesnego województwa poleskiego i północnych powiatów wołyńskiego - może pogłębić nasze rozumienie historii polskich nauk społecznych. Pomocą w realizacji tego celu będzie prezentacja niepublikowanych wcześniej obszernych fragmentów dokumentów osobistych - korespondencji i dziennika terenowego badacza - jako grupy źródeł dostarczającej uzasadnienia argumentom wywodu.

W momencie, o którym mówimy, Józef Obrębski miał 29 lat i właśnie uzyskał doktorat $z$ antropologii społecznej $w$ London School of Economics and Political Science. Podczas trzyletnich studiów (1930-1933) pod kierunkiem Bronisława Malinowskiego zdobył wysokiej klasy kompetencje w zakresie nieuprawianego dotąd w Polsce nowego kierunku antropologii, jakim był funkcjonalizm. Etnograficzną metodę terenową Malinowskiego praktykował podczas kilkumiesięcznych badań w górskich wsiach Macedonii ${ }^{5}$. Kiedy więc rozpoczynał ekspedycję poleską, posiadał zarówno wiedzę teoretyczną, jak i osobiste doświadczenie $w$ badaniu społeczności chłopskich. Jego etnograficzny kontakt z badanymi społecznościami, najpierw w Macedonii, później na Polesiu, miał miejsce w postfeudalnych, niezmodernizowanych wsiach Europy Wschodniej, naznaczonych peryferyjnością i podporządkowanych realnej i symbolicznej władzy grup dominujących. Ten klasowy wymiar prowadzonych badań współgrał z lewicową wrażliwością Obrębskiego, intelektualisty o nastawieniu równościowym i emancypacyjnym, ukształtowanego w środowisku tzw. postępowej inteligencji. Nie mógł nie zaważyć na jego wyborach i postawach również w obszarze działalności naukowej.

Zainteresowanie Obrębskiego europejskimi społecznościami chłopskimi wynikało także z faktu, że nie miał możliwości, jak inni uczniowie Malinowskiego, podjęcia badań w którejś z afrykańskich czy azjatyckich kolonii państw zachodnich (to naukowe marzenie zrealizował dopiero pod koniec lat czterdziestych, na Jamajce). Wieś bałkańska (w jego przypadku: macedońskie Porecze w strukturach państwa jugosłowiańskiego) i wschodniosłowiańska (białorusko-ukraińskie Polesie w strukturach II Rzeczypospolitej) dodatkowo reprezentowa-

\section{......}

2 O krystalizowaniu się w latach 20. i 30. XX w. polskiego pola nauk społecznych, kształtującego się w triadzie idei naukowych, procesu profesjonalizacji i polityki państwa, z uwzględnieniem kontekstu historycznego tych procesów, pisze Olga Linkiewicz w: (Linkiewicz, 2016a, 2016b, 2019).

3 Badania na Polesiu, w ramach programu Komisji Naukowych Badań Ziem Wschodnich, Obrębski prowadził od kwietnia 1934 do września 1936 r. (por. Engelking, 2001, 2007). Po 1936 r. kontynuował wspótpracę z KNBZW, kierując pracami terenowymi na Wołyniu (por. Grott, 2013, s. 119-120). Ten obszar jego działalności naukowej, znajdujący odzwierciedlenie w bardzo szczupłym zasobie źródeł, nie jest przedmiotem mojego zainteresowania w niniejszym artykule.

4 Wśród ważniejszych prac o Józefie Obrębskim (1905-1967), omawiających jego dzieło oraz kładących nacisk na nowatorstwo dokonań w nawiązaniu do badań na Polesiu, zob.: (Benedyktowicz, 2000; Borkowska, 2008, 2010; Engelking, 2001, 2007; Kutrzeba-Pojnarowa, 1979; Nowicka, 2006).

5 Na temat badań prowadzonych przez Obrębskiego w Macedonii zob. zwłaszcza: (Engelking, 2003, 2018; Halpern, 2002; Risteski, 2011). 
ły ugruntowane w tradycji etnograficznej przekonanie o ponadprzeciętnej archaiczności ich kultury i urządzeń społecznych. Motywacja Obrębskiego do badania właśnie tych regionów miała więc też silny fundament metodologiczny i teoretyczny: chodziło o aplikowanie etnograficznej metody terenowej i funkcjonalnego oglądu kultury w społecznościach nieegzotycznych, jak również o weryfikację żywych w etnologicznym mainstreamie przeświadczeń naukowych. Kiedy więc otworzyła się przed nim możliwość prowadzenia badań na Polesiu, był wśród etnologów swego pokolenia badaczem najlepiej przygotowanym i dysponującym nowatorskim na polskim gruncie instrumentarium badawczym.

Podzielana przez uczonych różnych dyscyplin, jak również szeroką publiczność w Polsce opinia o archaiczności Polesia, w zestawieniu z wynikami spisów ludności, które wykazywały w tym regionie ludność „nieokreśloną narodowościowo”, skłoniły polityków do uznania jego mieszkańców za grupę najłatwiejszą do polonizacji (por. Cichoracki, 2013; 2014). By temu politycznemu przedsięwzięciu dostarczyć naukowych argumentów, postanowiono rozpocząć na Polesiu wieloaspektowe badania, których wykonawcami mieli być przedstawiciele różnych dyscyplin nauki. Decyzja na szczeblu rządowym o wdrożeniu tego projektu, w którym szczególny nacisk miał być położony na terenowe techniki pozyskiwania danych, zbiegła się z powrotem Obrębskiego z Londynu. Wkrótce znalazł się w gronie jego wykonawców.

\section{OBRĘBSKI JAKO BADACZ POLESIA. EKSKLUZJA}

Zacznijmy od tych reakcji na ogłoszone przez Obrębskiego w 1936 roku wyniki badań, które świadczą o ich niezrozumieniu bądź odrzuceniu przez część środowiska etnograficznego.

Białoruski etnograf Marian Pieciukiewicz ${ }^{6}$, wychowanek ośrodka etnologicznego na Uniwersytecie Stefana Batorego w Wilnie, pisał, już z perspektywy powojennej, w jednym z prywatnych listów: „Żaden uczony w Związku Radzieckim nie powołuje się dzisiaj na genialne "prace naukowe» Josifa Wissarionowicza Stalina i żaden z polskich etnografów i socjologów, mówiąc o etnosie Polesia, nie powołuje się na byłego współpracownika polskiej międzywojennej "dwójki» - Józefa Obrębskiego, który stworzył z białoruskich Poleszuków jakiś nikomu nieznany naród "tutejszych»" (Pieciukiewicz, 2005, s. 100; list do Jerzego Turonka z 7.03.1969; tłum. z białoruskiego A.E.). Niemające odniesienia do rzeczywistości twierdzenie, jakoby Obrębski skonstruował koncepcyjnie "naród tutejszych", wraz z oskarżeniem go o agenturalność i dyskredytacją przez zestawienie ze Stalinem, nasuwają pytania o funkcję i długie trwanie niemerytorycznych opinii i niechęci personalnych w polu nauki.

W 1969 roku, kiedy Pieciukiewicz pisał te słowa, mógł znać tylko cztery przedwojenne artykuły Obrębskiego, opublikowane w "Sprawach Narodowościowych" (Obrębski, 1936b, 1936d) i "Przeglądzie Socjologicznym” (Obrębski, 1936a, 1936c). O tym, że białoruscy uczeni w II RP czytali jego prace, świadczy też nawiązanie przez Antona Łuckiewicza7 do artykułu Problem etniczny Polesia (Obrębski, 1936b) w szkicu (niepublikowanym i niedatowanym) Etnohraficznyja hranicy Biełarusi [Etnograficzne granice Białorusi]. Łuckiewicz omawia tu granice zasięgu języka białoruskiego i przywołuje ustalenia Obręb-

6 Marian Pieciukiewicz (1904-1983), etnograf, wychowanek Cezarii Ehrenkreutzowej, działał przed wojną w Wilnie, po wojnie w Toruniu. Prowadził badania na Białorusi i Podlasiu.

7 Anton Łuckiewicz (1884-1942), białoruski działacz narodowy, w latach międzywojennych kierowat Muzeum Białoruskim im. Iwana Łuckiewicza w Wilnie. 
skiego w odniesieniu do Polesia. Robi to jednak instrumentalnie, odwracając sens jego twierdzeń, by potwierdzić własne tezy, w tym głoszącą, iż "sama ludność Polesia jest świadoma swojej przynależności do narodu białoruskiego" (Łuckiewicz, bd, s. 2; tłum. z białoruskiego A.E.). Tymczasem Obrębski w tymże artykule pisał o „oporności, którą Poleszuk wykazuje w unarodowieniu go i [...] nieuchwytności jego sylwetki narodowościowej, która dziwi nas wszystkich: Polaków, Ukraińców i Białorusinów" i konstatował: "Iudzie Polesia - w swej przeważającej masie - nie są ani Ukraińcami, ani Białorusinami" (Obrębski, 2007d, s. 234 [1936b]). Być może to właśnie niesformatowana przez dyskursy nacjonalistyczne konceptualizacja „sylwetki narodowościowej” Poleszuków, jaką zaproponował Obrębski, kazała Pieciukiewiczowi widzieć w nim twórcę konceptu „tutejszych"?8. Konceptu, dodajmy, wytworzonego przez polską administracje (Cichoracki, 2013, s. 101); sam Obrębski kwitował go określeniem "niesławna rubryka "tutejszych»" (Obrębski, 2007a, s. 305) ${ }^{9}$.

Pieciukiewicz czy Łuckiewicz nie byli odosobnieni w dezinterpretacji bądź dezawuowaniu ustaleń Obrębskiego. Deprecjonował go też Iwowski etnograf Jan Falkowski1 ${ }^{10}$ który również badał pod kątem zróżnicowań etnicznych prawosławne społeczności chłopskie we wschodniej Polsce - w ukraińskich Karpatach. Ewidentnie nie rozumiejąc nieesencjalistycznego stanowiska Obrębskiego, zarzucał mu subiektywizm i brak ścisłości i potępiał za stosowanie "socjologicznego sposobu” w badaniu grup etnicznych, oceniając, że jego metoda sytuuje się „pod wieloma względami w jednym szeregu z rewelacjami różnych dyletantów"11 (Falkowski, 2006, s. 171-172).

Dla tych, którzy w przedmiocie przez niego badanym lokowali własne interesy naukowe, narodowe czy polityczne, Obrębski był trudny, jeśli nie niemożliwy do przyjęcia. Merytoryczne wyniki jego badań, choć ugruntowane we wnikliwym etnograficznym opisie rzeczywistości i najnowszych osiągnięciach teoretycznych nauk społecznych, nie zostały zintegrowane przez współczesny uczonemu naukowy dyskurs dotyczący etniczności i procesów narodotwórczych ${ }^{12}$. Politycznym zleceniodawcom badań natomiast nie dostarczyły narzędzi, które mogłyby wspierać ich politykę dyskryminującą mniejszości.

\section{MIĘDZY PROJEKTEM NAUKOWYM A MISJĄ CYWILIZACYJNĄ. POLITYCZNY KONTEKST PRZYPADKU OBRĘBSKIEGO}

Falkowskiego przywołałam tu nie tylko ze względu na różniący ich z Obrębskim paradygmat metodologiczny i przynależność do rywalizujących środowisk etnologicznych. Także - i przede wszystkim - dlatego, że obaj uczestniczyli w tym samym naukowym projekcie rządowym ${ }^{13}$, który m.in. żywo interesował elity białoruskie i który dla Pieciukiewicza ozna-

\section{......}

8 Por.: „[l]nterpretacje zjawiska czynione były również przez badaczy i polityków białoruskich oraz ukraińskich, wysuwających własne roszczenia narodowościowe wobec Polesia. Z takiego punktu widzenia zjawisko "tutejszości» było, rzecz jasna, negowane" (Cichoracki, 2013, s. 102).

9 O odmawianiu prawomocności terminowi „tutejsi” przez Obrębskiego, por. też: (Cichoracki, 2013, s. 104).

10 Jan Falkowski (1901 - ok. 1940), etnograf, uczeń i współpracownik Adama Fischera, prowadził badania w Karpatach Wschodnich.

11 Na temat tego typu postawy krytycznej, która „nadaje arogancji i ignorancji pozór umocowania metodologicznego", a także przeciwstawienia substancjalizm - relacjonizm w myśleniu naukowym, por. rozdz. Myśleć relacjonalnie w: (Bourdieu, 2001, s. 222-234).

12 O takiej integracji, której początek wyznacza bazujący na teorii Obrębskiego artykuł Włodzimierza Pawluczuka Białorusini jako grupa etniczna (1968), można mówić na dobrą sprawę dopiero po śmierci uczonego.

13 Udział etnologów z ośrodka Iwowskiego (Adam Fischer, Jan Falkowski, Józef Gajek) w pracach prowadzonych pod auspicjami Komisji Naukowych Badań Ziem Wschodnich oraz innych programach badawczych rea- 
czał „współpracę z "dwójką»". Rządowy program badawczy obejmował województwa wschodnie, w których ludność zaliczana do narodowości polskiej stanowiła statystyczną mniejszość. Polesiu, uznanemu za najlepiej rokujące dla polityki asymilacji narodowej ${ }^{14}$, a także traktowanemu jako teren istotny strategicznie ze względu na granicę ze Związkiem Radzieckim i szczególnego rodzaju cechy fizjograficzne, nadano priorytet.

W dyskursie publicznym wpisywano ów program w propagandowe kategorie misji cywilizacyjnej. Minister spraw wojskowych generał Tadeusz Kasprzycki15, kierujący rządową Komisją Naukowych Badań Ziem Wschodnich, nawoływał: „Musimy iść na wschód całą gromadą, [...] żeby go całkowicie nasycić kulturą polską i to, co zdobyto mieczem, umocnić przez wartości duchowe i gospodarcze" (Paprocki, 1938, s. 99). Jako obiekt tak określonej misji wskazywano „etnicznie obce” "grupy mniej lub więcej wyraźnie się krystalizujące" oraz „bierne narodowościowo, amorficzne masy”, z których „część [...] posiada nawet swoją prastarą prymitywną kulturę, ale obecnie masy te są w poszukiwaniu kultury wyższej" (Paprocki, s. 100, 99) ${ }^{16}$. Chodziło o słowiańskojęzyczne mniejszości, klasyfikowane przez administrację państwową jako mniejszość narodowa białoruska i ukraińska, bądź jako „tutejsi”, a składające się z grup o rozmaitych tożsamościach zbiorowych, definiowanych przez same zainteresowane podmioty w kategoriach zarówno narodowych, jak i anarodowych: wyznaniowych, stanowych bądź lokalnych (etnicznych).

Ta sama frazeologia przenikała oficjalne wypowiedzi uczestników pola naukowego, którzy pełnili funkcje w polu władzy. Sięgnijmy do exposé odnoszącego się do zagadnień, które miały stać się przedmiotem badań Obrębskiego, wygłoszonego przez akademickiego historyka i zarazem urzędnika ministerialnego związanego z Komisją NBZW - Władysława Wielhorskiego. Na założycielskim posiedzeniu Komisji, na którym przedstawił „Myśli przewodnie przy studiach Kresów Wschodnich" argumentował on, że "bezpostaciowość narodowa mas", "bytujących w prymitywie gospodarczym i społecznym" na Polesiu (jak również w Karpatach) stwarza szansę polepszenia statystyki narodowościowej na korzyść narodu państwowego. Uzasadniał, że „brak jednolitości oraz wyrazistości kształtów w indywidualnościach etnicznych najmłodszych i najsłabszych jakościowo, a zarazem najsilniejszych ilościowo żywiołów ukraińskiego oraz białoruskiego" jest czynnikiem sprzyjającym ich „wychowaniu” na rzecz narodu polskiego (cyt. za: Grott, 2013, s. 93-95).

Te rewindykacyjne cele polityczne, wskazywane przez decydentów, choć może to brzmieć paradoksalnie, nie przekładały się jednak w bezpośredni sposób na działalność badawczą poszczególnych uczonych, realizujących program naukowy Komisji ${ }^{17}$. Mimo że cel nadrzędny był polityczny, szczegółowe cele badań były poznawcze. Choć nie można wykluczyć, że wśród badaczy funkcjonowali agenci „dwójki”, absurdem byłoby założenie, że byli nimi wszyscy ${ }^{18}$. Program, adresowany do całego środowiska naukowego, przyciągał zarówno młodych badaczy, jak i tuzy nauki polskiej, zaś prestiżu dodawały mu cykliczne

lizowanych na polityczne zamówienie władz omawia O. Linkiewicz w: (Linkiewicz, 2016b). Tam także analiza kontrowersji między badaczami uznającymi odmienne paradygmaty teoretyczno-metodologiczne (ośrodek Iwowski vs Florian Znaniecki i Józef Obrębski) w kontekście splotu nauki i polityki.

14 W tym okresie funkcje wojewody poleskiego sprawował Wacław Kostek-Biernacki, gorliwy wykonawca opartej na przemocy polityki polonizacji wschodniosłowiańskich mniejszości (por. Cichoracki, 2009, 2012).

15 Więcej na temat działalności gen. Kasprzyckiego na styku polityki i nauki w kontekście procesów instytucjonalizacji i profesjonalizacji oraz kształtowania się nowoczesnych zastosowań nauk społecznych (ekspertyzy), zob. w: (Linkiewicz, 2016b, 2019).

16 Przytoczone cytaty pochodzą z wywiadu, którego gen. Kasprzycki udzielił czasopismu „Polska Zbrojna” (nr 267, 29.09.1936). Jego istotne fragmenty zostały przedrukowane w publikacji (Paprocki, 1938: 98-101], za którą je cytuję.

17 Programowi i organizacji tych badań poświęcona jest monografia Olgierda Grotta (Grott, 2013).

18 Co ciekawe, została udowodniona współpraca jednego z wykonawców programu - statystyka i demografa Samuela Fogelsona - z wywiadem radzieckim (Poczobut, 2013). 
zjazdy sprawozdawczo-naukowe, organizowane przez władze rektorskie uniwersytetów (w 1936 roku na Uniwersytecie Warszawskim - zjazd poleski, w 1938 roku na Uniwersytecie Jagiellońskim - zjazd karpacki). W tym kontekście zadziwia stwierdzenie amerykańskiego historyka Timothy'ego Snydera, piszącego o rewindykacji wyznaniowo-narodowej Wołynia, że to: „[a]rmia wysłała na Wołyń zespoły naukowców, które miały przeprowadzić badania "antropogeograficzne» oraz "etnosocjologiczne»" (Snyder, 2008, s. 218).

Choć Komisją NBZW kierował wojskowy, zaś zespoły naukowców realizowały program firmowany przez polityków, wśród których wraz ze zbliżaniem się wojny coraz większą rolę odgrywali wojskowi, nie były to badania prowadzone na zlecenie wojska. To nie „armia wysyłała” badaczy w teren, by przynieśli stamtąd odpowiedzi satysfakcjonujące jej polityczno-strategiczne zamówienie. Realizacja programu badawczego na ziemiach wschodnich przebiegała w ramach współpracy decydentów politycznych z uczonymi, reprezentującymi zarówno wszystkie państwowe uniwersytety ${ }^{19}$, jak i pozaakademickie instytucje naukowe i eksperckie. „Niezależnie od tego, jak sytuowali własną pracę naukową w relacji do rządowego programu, tylko nieliczni przedstawiciele nauk społecznych nie byli objęci projektem nauki stosowanej na użytek racji stanu. To zaangażowanie miało ciekawe konsekwencje dla trajektorii dyscyplin i wpływ na wewnętrzną dynamikę relacji między szkołami akademickimi" (Linkiewicz, 2019, s. 9; tłum. A.E.).

Uczeni byli dziećmi swojej epoki, uczestnikami polskiego życia politycznego i debaty publicznej. Zakres, w jakim oficjalna agenda polityczno-ideologiczna wpływała na wyniki ich badań, był kwestią indywidualną. Dominujący styl myślowy, skupiony wokół etnocentrycznej, wrogiej mniejszościom polskości, jaki zwyciężył w polskim establishmencie w drugiej połowie lat trzydziestych, profilował ich działalność naukową w rozmaitym stopniu. Zależało to m.in. od umiejętności krytycznego myślenia, stopnia konformizmu postaw i zachowań, poglądów politycznych, wreszcie od uprawianej dyscypliny nauki - językoznawcy zajmowali się w zasadzie obiektywnymi faktami językowymi ${ }^{20}$, badacze społeczni, z racji samego przedmiotu badań, nie zawsze byli wolni od wpływu mających charakter doksy kulturowych wzorów myślenia o wschodniosłowiańskich mniejszościach (por. Engelking, 2017), generujących siłą rzeczy aprioryczne założenia i przedsądy w nauce ${ }^{21}$. Wielu jednak, nie podzielających punktu widzenia i celów władzy, realizowało badania, dając pierwszeństwo nie agendzie polityczno-propagandowej, lecz imperatywowi naukowego poszukiwania prawdy.

Obrębski, uczony wierzący w nauke i skuteczność procedur opartych na jej prawach, konsekwentnie będzie odnosit się krytycznie zarówno od sugerowanych wykonawcom programu Komisji apriorycznych założeń badawczych, jak i jego kolonizacyjnych celów ujmowanych $w$ ideologiczne formuły. Ten drugi obszar poddawał analitycznemu oglądowi; język, mechanizmy i cele odnoszonej do Polesia propagandy były dla niego przej-

19 W Warszawie, Krakowie, Poznaniu, Lwowie i Wilnie.

20 W ramach omawianego tu programu badań powstały m.in. takie prace językoznawcze, jak: H. Friedrich, Obserwacje nad mowa wsi mazurskiej na Polesiu. Referat zgłoszony na I Zjazd Sprawozdawczo-Naukowy poświęcony Ziemiom Wschodnim; L. Ossowski, Zagadnienie językowe Polesia. Referat zgłoszony na I Zjazd Sprawozdawczo-Naukowy poświęcony Ziemiom Wschodnim; J. Tarnacki, Podziat językowy Polesia na podstawie faktów leksykalnych. Streszczenie referatu zgłoszonego na I Zjazd Sprawozdawczo-Naukowy poświęcony Ziemiom Wschodnim (wszystkie wydane przez Komisję Naukowych Badań Ziem Wschodnich, Warszawa 1936). Por. komentarz Obrębskiego do prac Ossowskiego i Tarnackiego w: (Obrębski, 2007b, s. 332-334).

21 Widoczne wpływy nacjonalistycznych i propagandowych koncepcji generowanych w rzeczywistości pozanaukowej nosi m.in. książka Stanisława Dworakowskiego (współpracownika terenowego Obrębskiego na Polesiu) Szlachta zagrodowa we wschodnich powiatach Wołynia i Polesia (1939). Więcej na temat politycznego zaangażowania tego badacza w „pracę nad odbudową polskości na naszych Kresach Wschodnich” zob. w: (Engelking, 2005, s. 184-187). 
rzyste. O swoim zamiarze badania tego dyskursu pisał do Malinowskiego w kontekście jego koncepcji magii językowej przedstawionej w Coral Gardens: „Dla Polesia b[ardzo] przydatna będzie koncepcja magji słowa we współczesnej propagandzie politycznej" (24.01.1935; LSE). Tego pomysłu badawczego nie zrealizował w postaci osobnego studium czy choćby szkicu, ale uwagi o kolonialnym charakterze polskiej polityki wobec ruskich chłopów i o stereotypie Poleszuka jako jednym z jej narzędzi przewijają się w jego pismach. Powrócę jeszcze do tego wątku w dalszej części tekstu.

\section{ZLECENIODAWCY I WYKONAWCY PROJEKTU BADAWCZEGO A CASUS OBRĘBSKIEGO}

Podmiotem sprawczym, odpowiadającym za program i zabiegającym o finansowanie badań22, była powołana do istnienia 2 marca 1934 roku Komisja Naukowych Badań Ziem Wschodnich, kierowana przez generała Kasprzyckiego. Była ona organem wykonawczym Komitetu do Spraw Narodowościowych przy Radzie Ministrów, a więc agendą rządową. Nie wojskową. Działalność Komisji koordynowało Biuro Organizacji Naukowych Badań Ziem Wschodnich. Najważniejszym partnerem naukowym Komisji był Instytut Badań Spraw Narodowościowych, działający aktywnie od 1926 roku, kiedy w wyniku zamachu wojskowego władze w kraju objął marszałek Józef Piłsudski, dając tym samym początek autorytarnym rządom sanacji23. Był to funkcjonujący jako stowarzyszenie prywatne niezależny think-tank, który skupiał największe autorytety akademickie w zakresie studiów nad mniejszościami narodowymi i etnicznością, a także działaczy politycznych (Grott, 2013; Serwański, Wrzesińska, 2006). Jako instytucja ekspercka mediująca między mniejszościami narodowymi a władzami, powiązana sieciami współzależności ze sferami rządowymi i parlamentarnymi, IBSN wywierał wpływ na politykę narodowościową państwa (Stach, 2016). Komisję i Instytut łączyły więzi personalne, przede wszystkim osoba „zakulisowego organizatora upolitycznionej działalności eksperckiej" (Linkiewicz, 2016b, s. 19) - Stanisława Józefa Paprockiego, sekretarza generalnego obu instytucji oraz redaktora naczelnego wydawanego przez Instytut dwumiesięcznika „Sprawy Narodowościowe” (1927-1939). Znaczna część uczonych realizujących program badawczy Komisji była członkami lub współpracownikami Instytutu. Józef Obrębski został jego członkiem rzeczywistym 28 marca 1936 roku.

Prowadzone w ramach programu badania w województwach wschodnich, traktowane jako „przekrojowe studia o strategicznym znaczeniu dla państwa polskiego” (Grott, 2013, s. 92), obejmowały kompleksowo rozumiane zagadnienia ekonomiczne i narodowościowe. Ich wykonawcami byli ekonomiści, geografowie, statystycy, demografowie, antropolodzy fizyczni, specjaliści od zagadnień rolnictwa, historycy, językoznawcy oraz etnolodzy i etnografowie (por. Grott, 2013). Wśród zajmujących się Polesiem spotykamy m.in. takie

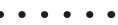

22 „Badania naukowe Komisji prowadzone przede wszystkim przez Instytut Badań Spraw Narodowościowych finansowane były z kilku źródet. Wskazuje na to preliminarz budżetowy Komisji z 1935. Spodziewano się wpływów z Funduszu Kultury Narodowej (200 000 zł), Funduszu Pracy (180 000) oraz z Ministerstw: Spraw Wewnętrznych (10 000), Wojska, Spraw Zagranicznych, Opieki Społecznej, Przemysłu i Handlu, Oświaty i Wyznań Religijnych, Rolnictwa i Reform Rolnych (po 5000), Sztabu Głównego (również 5000) oraz banków (w sumie 28 000)" (Serwański, Wrzesińska, 2006, s. 87-88).

23 Badacze podkreślają mający miejsce po zamachu majowym zwrot w relacjach między władzami państwowymi a środowiskiem naukowym w kierunku zastosowań nauk społecznych do celów politycznych, por. (Linkiewicz, 2016a, s. 177-178). 
nazwiska, jak Witold Doroszewski, Henryk Friedrich, Leszek Ossowski, Józef Tarnacki, Samuel Fogelson, Tadeusz Henzel, Alfons Krysiński, Bogdan Zaborski, Ludwik Grodzicki, Eugeniusz Mejer czy Witold Staniewicz; wśród badaczy Karpat (gdzie badania były prowadzone równolegle ${ }^{24}$ ): Jan Janów, Stefan Hrabec, Zdzisław Stieber, Stanisław Leszczycki, Jan Falkowski czy Stanisław Vincenz. Otwarcie deklarowanym celem decydentów i sponsorów była bowiem - jak ujął to sam Kasprzycki - troska o to, aby „państwowo-narodowa misja cywilizacyjno-kulturalna mogła się oprzeć na gruncie pełnego i wszechstronnego przygotowania" (Paprocki, 1938, s. 16). Interpretacja i zakres zastosowania wyników naukowych współtworzących owo „przygotowanie” należały do polityków, sam proces badań nie był jednak - jak wynika z analizy przypadku Obrębskiego - bezpośrednio sterowany przez polityczne czy ideologiczne naciski (choć zależał od zewnętrznych czynników administracyjno-finansowych).

Do podobnego wniosku doszedł Piotr Cichoracki25:

Świadectwem tego, że nacisk państwowego protektora tychże prac nie był obezwładniający, a badacze formułowali opinię swobodnie i dzielili się nią otwarcie, były bardzo pesymistyczne konkluzje Józefa Obrębskiego, bez wątpienia autora najbardziej pogłębionych studiów o tematyce poleskiej. Wnioski te dotyczyły negatywnego wpływu administracji na stosunek prawosławnej ludności Polesia do państwa. Wygłaszał je publicznie w obecności przedstawicieli najwyższych władz państwowych, wywołując zresztą ożywioną dyskusjęe (Cichoracki, 2013, s. 103).

Obrębski należał do grupy badaczy społecznych, o których Olga Linkiewicz pisała: „Część tych uczonych nie popierała linii politycznej sanacji; motywowało ich przekonanie, że wiedza ekspercka może prowadzić do postępu społecznego. Ich stanowisko w kwestii zaangażowania uczonego było oparte na wizji państwa jako dobra wspólnego, podlegającego wspólnej odpowiedzialności" (Linkiewicz, 2019, s. 12; tłum. A.E.). Przypadek Józefa Obrębskiego, działającego poza strukturami państwowych uniwersytetów ${ }^{27}$, zależnego od podmiotów finansujących jego badania, niepopierającego polityki rządu wobec mniejszości, choć przekonanego, że "należy pracować w Polsce i tylko dla Polski”28, a przy tym myślącego w sposób zarazem krytyczny i odkrywczy, stanowi w tym kontekście złożoną, niejednowymiarową ilustrację zestawu czynników warunkujących zakres autonomii uczonego. Jak również możliwości oddziaływania twórczo uprawianej antropologii na rzeczywistość społeczną.

\section{- . . •}

24 Ogółem pod auspicjami Komisji działało sześć regionalnych grup badawczych: Poleska (później PoleskoPodolska; kier. L. Grodzicki), Huculska (prowadzona przez Towarzystwo Przyjaciół Huculszczyzny), Łemkowska (kier. J. Smoleński), Lwowska (kier. T. Bigo), Wileńska (później Ziem Północno-Wschodnich; kier. W. Wielhorski) i Chełmsko-Wołyńska (kier. W. Krzyżanowski) (por. Grott, 2013, s. 103 i passim).

25 Analogicznie J. Serwański i K. Wrzesińska: „Jakikolwiek bytby polityczny kontekst podejmowanych przez rząd wysitków w odniesieniu do Ziem Wschodnich, faktem pozostaje powołanie Komisji o charakterze naukowym i zapewnienie jej materialnych podstaw do prowadzenia obiektywnych badań. Jak dalece i w jaki sposób ich wyniki wykorzystano w bieżacej polityce rzadu, stanowi kwestię odrębna. Na posiedzeniu Biura w październiku 1934 r. Stanisław Swianiewicz (zajmujący się badaniami na terenie woj. wileńskiego) przestrzegał jednak, by w podejmowanych pracach nie wykraczano poza cele naukowe" (Serwański, Wrzesińska, 2006, s. 85)

26 Na temat tej dyskusji zob. dalej.

27 Obrębski wykładał w Wolnej Wszechnicy Polskiej i innych niepaństwowych instytucjach akademickich (Seminarium Narodowościowe IBSN, Instytut Pedagogiczny ZNP). Prace etatową otrzymał dopiero w listopadzie 1936 r., gdy został wicedyrektorem nowo utworzonego Państwowego Instytutu Kultury Wsi, którym kierował Józef Chałasiński. Także i wtedy, jak wynika z dokumentów osobistych, liczył się z możliwymi ograniczeniami autonomii: „O Józiu można teraz mówić "pan radca». Dostał posadę w Instytucie Kultury Wsi [...]. Perspektywa naukowego opracowywania różnych zagadnień. Zobaczymy, czy nie będzie $w$ tym za wiele skrępowań i dyrektyw z góry. Ale na razie to najlepsze z tego, co go tu mogło spotkać (naukowo)" (A. Obrębska-Jabłońska do K. Nitscha, 29.11.1936; (Skarżyński, Smułkowa, 2018, s. 307)).

28 Jest to sformułowanie Obrębskiego z listu do matki, uzasadniające nieprzyjęcie przez niego propozycji Malinowskiego, by po doktoracie nadal wspótpracował z nim w Londynie (M. Obrębska do J. Obrębskiego, 27.04.1957; OC) 
Wnikliwsze przyjrzenie się przypadkowi Józefa Obrębskiego umożliwiają dokumenty osobiste. Zacznijmy od obszernego fragmentu jego listu do Marii Znamierowskiej-Prüfferowej, wówczas asystentki w Zakładzie Etnologii USB w Wilnie. List, pisany z Drohiczyna Poleskiego w listopadzie 1934 roku, a więc pół roku po rozpoczęciu ekspedycji, odnosił się do próby dokooptowania do ekipy badawczej absolwentki geografii, mającej przeciwstawne niż Obrębski poglądy polityczne (kandydaturę tę prędko storpedowali decydenci w IBSN).

Pisałaś [...], że Ciebie dziwi to branie pod uwage poglądów politycznych terenowca. Otóż widzisz, sprawa się przedstawia $w$ ten sposób, że $w$ naszych badaniach poglądy te znaczą b[ardzo] wiele. Chodzi o to, ażeby pracownik, który tu wchodzi w teren i bada świadomość narodową Poleszuków, nie dał się zasugerować ogólną atmosferą administracyjno-polityczną Polesia, i nie wyciągat przedwczesnych wniosków co do anarodowościowych bezbarwnych postaw Poleszuków. Pracujemy tu w gruncie rzeczy w b[ardzo] ciężkich i niesprzyjających warunkach. Z jednej strony mamy administrację miejscową, szowinistyczną, pełną zapędu polonizacyjnego, wpatrzoną z zachwytem w ostry kurs obecnej polityki, przepowiadającą w okresie najbliższej piatiletki kompletną polonizację Polesia - z drugiej zaś strony Poleszuka: nieufnego, podejrzliwego, zapierającego się przy pierwszym kontakcie wszelkich sympatii proukraińskich lub probiałoruskich, wyrażającego nawet swoją gotowość pójścia za życzeniem władzy w tych wszystkich sprawach. Pracując, musimy zważać na to, aby nie wywołać nieodpowiedniego rezonansu ani śród administracji (gdyż to mogłoby wysoce utrudnić badania), ani śród ludności, którą się bada w sposób taki, by nie mogła ona zorientować się, o co chodzi. Wiadomości, jakie miałem [...], osobiście b[ardzo] mnie pociągały do zaangażowania p. Petrusewiczowej: jako [endeczka] byłaby ona czuła na błędy miejscowej administracji; jako żona radykała ${ }^{29}$ miałaby otwarty horyzont dla zrozumienia miejscowego radykalizmu, który też jest przedmiotem naszych badań. Obawiałem się tylko jednej rzeczy u niej: typowej dla nacjonalisty polskiego postawy lekceważenia lub bagatelizowania tych ułamków świadomości narodowej, które staramy się dyskretnie i kunsztownie wyłowić od pozornie obojętnego i kompromisowego Poleszuka. Piszę to wszystko tak obszernie dlatego, że nie chciałbym, abyś sądziła, że poglądy polityczne u kogokolwiek mogą wpływać w ten czy inny sposób na mój stosunek do niego. Odgrywają one o tyle tylko rolę, o ile mogą przesądzać w ten czy inny sposób o postawie badacza w stosunku do obiektu badań (13.11.1934; MET).

Współpracownik terenowy Obrębskiego, student Prüfferowej Zygmunt Korybutiak ${ }^{30}$, dawał wyraz ich stanowisku wobec politycznego kontekstu badań bez wnikania w dylematy metody i etyki: „Praca [...] jest nie tylko ciężka, ale i niebezpieczna, gdyż godzi w politykę obecnego wojewody ${ }^{31}$, która nie jest wcale humanitarna, ani też celowa. [...] Tak że, jak się Pani dowie o tem, że jestem w Berezie Kartuskiej - proszę się nie dziwić zbytnio" (22.10.1934; MET). Sarkastyczna uwaga o obozie koncentracyjnym w Berezie Kartuskiej, gdzie więziono politycznych przeciwników władzy, nie wymaga dodatkowego komentarza.

Członkowie ekipy terenowej - mimo że zaopatrzeni w dokumenty wystawione przez rządową komisję i przybywający ze stolicy państwa, by realizować państwowy program

\footnotetext{
29 Mowa o absolwentce geografii na USB, Elizie Petrusewiczowej (1908 - ok. 1941). W latach 1929-1934 była ona słuchaczką wykładów Cezarii Ehrenkreutzowej, jesienią 1934 r. - świeżo wypromowaną magister; aktywnie interesowała się etnografią i etnologią. Była żoną Kazimierza Petrusewicza, biologa, komunisty, członka wileńskiej grupy "Po prostu”.

30 Zygmunt Korybutiak (1907-1989), etnograf, wychowanek Cezarii Ehrenkrutzowej, po wojnie na emigracji w Australii. Prowadził badania na Wileńszczyźnie i Polesiu. O Korybutiaku jako badaczu Polesia i współpracowniku Obrębskiego pisałam szerzej w: (Engelking, 2006).

31 Chodzi o Wacława Kostka-Biernackiego.
} 
badawczy - musieli się mierzyć z podejrzliwością lokalnej administracji i biurokratycznymi przeszkodami. Mówią o tym listy Korybutiaka do Obrębskiego pisane z terenu latem 1935 roku:

Miałem między innymi parę incydentów z policją [...]. [P]owiedziałem komendantowi, że pokazanie swego zaświadczenia uważam li tylko za czczą formalność, oczywista dyskutowaliśmy długo na ten temat, starałem się przekonać tego kacyka o słuszności swych wywodów.

[...] Przed paru dniami byłem w starostwie łuninieckim [...] i niestety odmówiono mi prawa badania do 9 [bieżącego miesiąca] ze względu na jakieś tam operacje wojskowe w tym akurat terenie [...] (17.08.1935 i 4.09.1935; AR).

W newralgicznym politycznie terenie, jakim było Polesie, należało w kontaktach z władzami i lokalnymi elitami wykazywać talenty dyplomatyczne i kompetencje negocjacyjne, zaś z mieszkańcami wsi - biegłość w sztuce pozyskiwania zaufania, czego warunkiem wstępnym było posługiwanie się ich językiem. Oprócz całej palety miękkich umiejętności niezbędnych antropologowi-terenowcowi ${ }^{32}$, badania - ze względu na brak infrastruktury komunikacyjnej i udogodnień cywilizacyjnych na Polesiu - wymagały też dużej wytrzymatości fizycznej33.

Źródłem obiektywnych trudności, przed jakimi stawał Obrębski wraz ze współpracownikami, byli także zleceniodawcy badań oraz konfiguracja otoczenia naukowego. Mam na myśli finansowe uwarunkowania ekspedycji i szczupłość wykwalifikowanych kadr w tworzącym się dopiero polskim środowisku badaczy społecznych. W kraju nie było doświadczonych terenowców, zdolnych pracować zgodnie z paradygmatem metodologicznym Malinowskiego i wymaganą przez Obrębskiego empatyczną i neutralną politycznie postawą w relacji badacz-badany; będąc przekonanym, że w tego rodzaju badaniach "swiatopogląd polityczny pracownika nie da się idealnie odseparować od przedmiotu badań" (Obrębski do Prüfferowej, 29.09.1934; MET), stawiał współpracownikom wymóg krytycznej samoświadomości metodologicznej. Kolejnych kandydatów - przy czym część z nich narzucał mu IBSN - Obrębski szkolił dopiero w terenie ${ }^{34}$; adepci na terenowców się wykruszali, zaś z powodu ograniczania funduszy przez Komisję NBZW ostatecznie pozyskał mniej współpracowników niż pierwotnie zamierzał. Najbardziej stabilnym i profesjonalnym członkiem zespołu okazał się Zygmunt Korybutiak (prowadził badania w 1934 i 1935 roku, był też obecny na zjeździe poleskim w 1936 roku), krócej, choć intensywnie pracował w terenie Stanisław Dworakowski35 (latem i jesienią 1935 roku).

Wgląd w tę dynamikę finansowych, personalnych i organizacyjnych kłopotów ekspedycji dają listy do Prüfferowej; niestety nie zachowała się dwustronna korespondencja prowadzona przez nią z Obrębskim i Korybutiakiem.

32 Kryteria, według których Obrębski dobierał współpracowników terenowych, formułował w listach do Prüfferowej: „Gotów jestem akceptować i popierać każdego, byleby był dostatecznie młody, inteligentny, podatny i z terenowem przeszkoleniem”; , Najlepiejby było, żeby to był ktoś mówiący po ukraińsku”; , "[C]zy i jak długo pracowała w terenie? Czy wytrzymała i zdrowa? Czy zna któryś z języków: białoruski, ukraiński, rosyjski? Jakie jest jej wyrobienie społeczno-polityczne?" (13.09.1934, 14.09.1934, 19.09.1934; MET).

33 "[P]raca terenowa jest ciężka, wyczerpująca i męcząca nawet dla mężczyzny" (Obrębski do Prüfferowej, 18.11.1934; MET). „Zrobitem pieszo 594 km w rozmaitych warunkach terenowych i atmosferycznych lepszych i gorszych, mimo to jestem jednak w formie dotychczas" (Korybutiak do Obrębskiego, 17.08.1935; AR).

34 "Obecnie oczekuję Korybuciaka - wyjade zapewne z nim w teren, nie czekając na innych. Choć wolałbym wszystkich mieć z miejsca razem, żeby na zbyt długi okres czasu nie rozciągać "seminarjum terenowego"" (Obrębski do Prüfferowej, 18.09.1934; MET).

35 Stanisław Dworakowski (1907-1976), etnograf, wychowanek Stanisława Poniatowskiego, związany z Warszawą i Białymstokiem. Prowadził badania na Polesiu i Podlasiu. O Dworakowskim jako badaczu Polesia i współpracowniku Obrębskiego pisałam szerzej w: (Engelking, 2005). 
W tej chwili dowiedziałem się o nowej komplikacji w naszych badaniach. Mój współpracownik, p. Chromiński ${ }^{36}$, po rozkoszach perypetyj poleskich zrezygnował z dalszej pracy [...]. Wobec tego wakują [...] 2 miejsca. [...] Jeśli miałabyś kogoś na widoku w Wilnie [...], bądź łaskawa dać mi znać możliwie szybko [...]. Choć oczywiście tutaj nic nie jest pewne: możliwe, że uda mi się znaleźć kogoś na bruku warszawskim. Wolałbym jednak, aby to był ktoś z uczniów p. Ehrenkreutzowej, gdyż niestety mam małe zaufanie do uczniów Poniatowskiego.

[...] Ja tu pozatem próbuję znaleść kogoś w Warszawie: u Czarnowskiego, Rychlińskiego i Orszy-Radlińskiej. Wątpię jednak, czy to się uda.

[...] Żałuję bardzo, że nie przewidziałem takich możliwości kandydatów z Wilna, jakie istnieją. W międzyczasie bowiem otrzymatem propozycję co do zaangażowania dwuch innych: jednego Poleszuka, drugiego - «amerykańskiego socjologa» ${ }^{37}$. Obu prawdopodobnie z rozkoszą bym zamienit na Turkowskiego ${ }^{38}$ lub geografkę ${ }^{39}$. Chwilowo jestem związany temi kandydaturami - choć jeszcze nic pewnego.

[...] Próbowatem przeforsować kandydaturę p. Petrusewiczowej w Instytucie, ale napotkałem na dość silne sprzeciwy ze względu na płeć. Mam wrażenie, że ostatecznie nic z tego nie będzie. [...] Bardzo Ci dziękuję za pomoc w zwerbowaniu Korybutiaka. Zanosi się na to, że ostatecznie na jego niemal jedynych barkach spoczną badania terenowe - gdyż drugi towarzysz pracy poleskiej, którego mi narzucił Instytut ${ }^{40}$, nie zapowiada się niestety obiecująco. Żałuję bardzo, że nie udało mi się pozyskać Turkowskiego (Obrębski do Prüfferowej, 13.09.1934, 14.09.1934, 18.09.1934, 29.09.1934; MET).

[P]. P[etrusewiczowa] byłaby chyba, jako geografka, lepszą o wiele od naszego Poleszuka prawnika, który bardzo źle sobie daje radę z terenem.

[...] Niestety teraz skutkiem uchwalenia budżetu na badania będziemy musieli pracę $w$ terenie ograniczyć do bardzo powierzchownej identyfikacji i szybkiego przejazdu, robiąc dość rzadkie punkty etno-socjologiczne. [...] [Z]marł śp. Dyrektor Świechowski", nie otrzymaliśmy na czas pensji i nie mogliśmy wyjechać dalej.

[...] Mniej więcej około 20 XII będziemy chyba w Warszawie, dlatego że zimowe badania terenowe Komisja przerwała ze względu na budżet. [...] [M]uszę śpieszyć, bo jest już późno, a dziś mamy jeszcze kilkanaście km drogi po deszczu i trzeba szukać podwody (Korybutiak do Prüfferowej, 22.10.1934, 7.11.1934, 13.11.1934; MET).

[Z]aszły niespodziewanie dwie nagłe katastrofy: śmierć Świechowskiego, który patronował naszym badaniom, i b[ardzo] znaczne ograniczenie kredytów na prace etnosocjologiczne. Z 1200 zł miesięcznie, które były w projekcie, spadliśmy do 500, co ledwo starczy na mnie i na Korybutiaka z zawieszeniem na jakiś czas prac terenowych, które są za kosztowne na obecny budżet. Tak więc cała sprawa rozbudowy badań została pogrzebana. Żal mi tego bardzo. [...] [P]odobno posiadasz w Muzeum dla użytku terenowców aż 5 kożuszków [...]. Czy - o ile nie są one w użyciu - można by było prosić Ciebie o przysłanie jednego z nich dla mnie? Mieliśmy sobie zamiar posprawiać takie kożuchy tu na miejscu - wobec tego jednak, że nam zwinięto badania na zimę i zgilotynowano kredyty - odstąpiliśmy od zamiaru. Tymczasem zamarudziliśmy i badania przeciągną się nam dłużej niż przypuszczaliśmy (Obrębski do Prüfferowej, 13.11.1934; MET).

\section{$\cdots \cdot \cdots$}

36 Więcej o Romanie Chromińskim, zob. (Engelking, 2004).

37 "Poleszuk" to Jan Teodorowicz, prawnik rodem z Pińska, o którego niekompetencji terenowej jest mowa W dalszych listach (por. Engelking, 2004); osoba „amerykańskiego socjologa” pozostaje niezidentyfikowana (mógt tu wchodzić w grę Teodor Abel).

38 Lucjan Turkowski (1905-1976), etnograf, uczeń Cezarii Ehrenkrutzowej, działał przed wojną w Wilnie i Warszawie, po wojnie na emigracji w Wielkiej Brytanii. Prowadził badania na Wileńszczyźnie i w Palestynie.

39 Mowa o Elizie Petrusewiczowej.

40 Mowa o Janie Teodorowiczu.

41 Marian Świechowski (1882-1934), działacz polityczny, publicysta, znawca problematyki litewskiej i białoruskiej. Kierownik naukowy Instytutu Badań Spraw Narodowościowych, referent ds. spraw narodowościowych w Prezydium Rady Ministrów, także pracownik Wydziału Narodowościowego MSZ. 
Przytoczone fragmenty listów pokazują, jak licznym ograniczeniom zewnętrznym podlegała autonomia Obrębskiego jako kierownika badań. Jego wpływ na skład zespołu badawczego był niewielki, fundusze niepewne i niewystarczające. Wieloaspektowa zależność antropologa-terenowca od instytucji zamawiających i finansujących jego pracę i od woli decydentów w ich łonie - okoliczności współkształtujące badania terenowe od początku istnienia dyscypliny - w przypadku poleskich badań Obrębskiego znacznie zawęziła zakres realizacji wyjściowych założeń projektu, zwłaszcza metodologicznych. Właśnie to musiał mieć na myśli, gdy pisał Malinowskiemu, że nie bierze pod uwagę badań prowadzonych na Polesiu jako podstawy przyszłej habilitacji42: „[...] gdyż mam pewne wątpliwości co do tego, czy Polesie [...], jako obciążone szeregiem braków metodycznych, możnaby było brać w tym względzie pod uwage" (24.01.1935; LSE). Z powodu ram, w jakich przyszło mu działać, nie mógł, tak jak na macedońskim Poreczu, spełnić większości kryteriów metody terenowej Malinowskiego. Badania poleskie miały więc charakter nie tyle długotrwałej stacjonarnej obserwacji uczestniczącej, ile „ekstensywnej terenówki”43 (por. Engelking, 2001, 2007).

Zestaw dokumentów osobistych istotnych dla zrozumienia uwarunkowań ekspedycji - w tym wypadku jej lokalnego kontekstu politycznego - dopełnia dziennik obserwacji z pierwszych dni pobytu Obrębskiego na Polesiu w maju 1934 roku. Pisząc dla siebie, bez ogródek wyraża w nim opinie na temat polityki państwa realizowanej tu przez jego przedstawicieli na różnych szczeblach administracji. Z ironią i sarkazmem odnotowuje obserwowane u poszczególnych funkcjonariuszy, wdrażających formułowany z aplauzem program polonizacji („,panpolonizacji”) Polesia, zachowania, postawy i poglądy świadczące m.in. o popieraniu przemocy i biurokratycznej opresji jako metod działania, o dehumanizowaniu lokalnej ludności i pogardzie wobec niej (choćby poprzez rzutowanie na nią negatywnego stereotypu Poleszuka), czy po prostu o ignorancji (dotyczącej np. sytuacji językowej i socjolingwistycznej w terenie). Punktuje wyższościowe narowy i ślepotę polskiej administracji na faktyczne położenie poleskich chłopów. Jednocześnie nie pomija przykładów pozytywnych - analitycznie szkicuje strategie postępowania „prawdziwego urzędnika na usługach ludności", komendanta posterunku policji w leżących na wschodnich rubieżach województwa poleskiego Czuczewiczach, którego postrzega jako ucieleśnienie ideału władzy miejscowej. Oto najbardziej znaczące fragmenty tych zapisków:

\section{V. Związek rezerwistów - droga do kultury polskiej. Argument materjalny}

Przyjazd do Brześcia. Wizyta u p. Rolewicza ${ }^{44}$. Pierwsze wzmianki o państwo-twórczym programie naszego p[ana] wojewody: przeciwstawić destrukcyjnej robocie komunistów itd. konstrukcyjną propagande rządu: organizację rezerwistów, opanowującą gromady wiejskie, mającą wpływ na życie wsi, wychowującą ją w duchu państwowym itd. Pan R. nie jest iluzjonistą: na początek trzeba przemawiać argumentem materjalnym: rezerwiści otrzymują czapki, buty itd. Pan R. jest niezbicie przekonany, że to jest droga do kultury polskiej na kresach.

W trakcie rozmowy telefon z Prużany: w związku z wyborami - "warcholstwo» miejscowych, grupujących się w blok, przeciwstawiający się polityce wyboru grupy błagonadiożnej. Meldunek: ten już siedzi, ten unieszkodliwiony itd. Pan R. jest radośnie zadowolony: nowy krok na drodze szerzenia KP [tj. kultury polskiej] w Prużańskiem zrobiony.

\footnotetext{
42 Podstawe jego habilitacji, uzyskanej w 1946 r. na UW, stanowiła jednak praca oparta na badaniach poleskich: monografia Polesie archaiczne, którą napisał podczas okupacji niemieckiej (Obrębski, 2007f).

43 Sformułowanie użyte przez Obrębskiego w liście do Prüfferowej (18.09.1934; MET).

44 Kazimierz Rolewicz (1898-1986), bliski współpracownik Kostka-Biernackiego, naczelnik Wydziału Bezpieczeństwa w Urzędzie Wojewódzkim w Brześciu, "uważany za faktycznego zastępcę wojewody” (Cichoracki, 2009, s. 196).
} 


\section{V. Poleszuk w oczach cywilizatorów i władzy}

Wizyta u Starosty [w Łunińcu]. [...] Opowiada o różnych akcjach, zjednujących ludność. W gruncie rzeczy informacja żadna: światopogląd państwowy: polonizacja, cywilizacja. Ludność miejscowa nie posiada swego języka; język miejscowy: mieszanina rosyjskiego i polskiego. Dominuje wierzenie w "polskość» Poleszuka. Język miejscowy to "zepsuty polski», który oczywiście trzeba naprawić. (Uwaga: Maniery wojskowe w starostwie. Komenderowanie ludnością: wstać, P[an] St[arosta], usiąść, już go niema).

Rozmowa z instruktorem oświaty pozaszkolnej. To samo przekonanie o zepsutym języku polskim. Prócz tego wizerunek urzędowy Poleszuka: Poleszuk leniwy; Poleszuk rozrzutny; Poleszuk pijak; Poleszuk niegospodarny. Gospodarny, pracowity, oszczędny i wstrzemięźliwy tylko kolonista polski. W nawiasach: na moją propozycję nawiązania kontaktu instruktor pyta o oficjalne pisma: od kuratora itd. Wszędzie red tape ${ }^{45}$.

\section{Właściwy człowiek na właściwem miejscu}

Rozmowa z komendantem posterunku. Komendant sprawia jaknajlepsze wrażenie. [...] Entuzjasta, energiczny, tolerancyjny, nie-legalista, nie-biurokrata, prawdziwy urzędnik na usługach ludności.

Metody of dealing with the peasants ${ }^{46}$ : przemawianie do ambicji - posługiwanie się opinją publiczną. Pomoc ludności: pieniężna i inna itp. Przemilczanie drobnych przewinień, unikanie protokułów (idą tylko w ważnych sprawach). Dzięki temu przychodzą do niego we wszystkich sprawach: nietylko policyjnych, również kłopotach małżeńskich itd. Komendant jako rozjemca, doradca, przyjaciel, instruktor, instrument publicznej opinji; obrońca ludności przed twardą literą prawa i jego nonsensów itp. Użytek polskiego ograniczony do powitań - sam komendant mówi z ludnością językiem miejscowym - używa go równie biegle jak każdy wieśniak - i z chęcią go używa. Traktuje swoją służbę nie jako policyjny nadzór - kontrolę - szpiegostwo etc., ale jako obronę ludności przed bezbronnością wobec prawa, nadużycia[mi] urzędników i karjerowiczostwem samorządowem, systemem donosicielstwa i doniesień karnych popieranych i wymaganych przez starostwo dla walki z elementem antypaństwowym. [...] Pomoc komendanta w sprawach budowlanych; pisanie podań etc. Faktycznie: bóg opiekuńczy ludności miejscowej. Komendant post[erunku] w Czuczewiczach jest dowodem, czym władza miejscowa może być - ideałem do którego dążyć się powinno.

\section{Nauczyciel. Panpolonizacja [Czuczewicze]}

Rozmowa z żoną kierownika szkoły. Optymistka państwowo-twórcza: wyraża niezłomną nadzieję: w niedługim czasie ludność będzie polska, będzie mówić tylko po polsku. Już teraz twierdzi, że dzieci miejscowe w zabawie między sobą mówią po polsku (a nie - własnemi uszami słyszałem). [...] W wąskim horyzoncie nauczyciela ludowego: akulturyzacja Poleszuka, pozyskanie go dla państwowości: nauka języka polskiego, polonizacja kompletna. Magiczna wiara w potęge języka "ojczystego" - polonizacja ma rozwiązać wszelkie faktyczne problemy gospodarcze i społeczne, które są klęską i tragedją ludności Poleskiej (OC).

\section{PARADYGMAT BADAWCZY OBRĘBSKIEGO A POLITYCZNO-ADMINISTRACYJNY KONTEKST PROJEKTU}

Komisja Naukowych Badań Ziem Wschodnich, o czym była już mowa, niezależnie od tego, iż należała do podmiotów realizujących kolonizacyjno-asymilacyjną politykę rządu, w zasadzie pozostawiała badaczom wolną rękę, gdy chodzi o kwestie teoretyczno-metodologiczne. Nie było przeszkód, by kierowali się wskazaniami najwybitniejszych polskich uczonych

\footnotetext{
45 Red tape (ang.) - przerost biurokracji.

46 Dealing with the peasants (ang.) - postępowanie z chłopami.
} 
i ekspertów, którzy swoje teorie, metody i wytyczne dla zastosowań nauk społecznych kształtowali w dialogu z nauką światową. Czołowym teoretykiem i autorytetem w tym zakresie był Florian Znaniecki, którego uczeń i współpracownik Stanisław Orsini-Rosenberg już na przełomie lat dwudziestych i trzydziestych aplikował jego ustalenia teoretyczne do programów badań socjologicznych (Orsini-Rosenberg, 1929, 1930). Powstawały one w kierowanym przez Znanieckiego Polskim Instytucie Socjologicznym w Poznaniu, który w latach trzydziestych nawiązał współprace z warszawskim Instytutem BSN. Opublikowany w "Sprawach Narodowościowych" w 1930 roku Program badań socjologicznych w zakresie zagadnień narodowościowych w województwach wschodnich Rzeczypospolitej Polskiej Orsiniego-Rosenberga (Orsini-Rosenberg, 1930), zakorzeniony teoretycznie w socjologii humanistycznej Znanieckiego i jako fundamentalne założenie metodologiczne przyjmujący perspektywę współczynnika humanistycznego, podkreślał konieczność prowadzenia badań „w interesie nauki i zracjonalizowanej polityki narodowościowej” (Orsini-Rosenberg, 1930, s. 45). Autor Programu..., wskazujący jako rzecz oczywistą rozpatrywanie badanych zagadnień „z pominięciem wszelkiej nienaukowej oceny" i „przez ludzi najzupełniej bezstronnych" 47 (Orsini-Rosenberg, 1930, s. 23, 36) deklarował: "Jedynem kryterjum, zgodnie ze stanowiskiem humanistycznem, musi tu być punkt widzenia samego osobnika i grupy, do której go zaliczają" (Orsini-Rosenberg, 1930, s. 26).

Obrębski, czynnie podzielający wprowadzoną do antropologii przez Malinowskiego dyrektywę uwzględniania „punktu widzenia tubylca”, w oczywisty sposób identyfikował się z tą perspektywą ${ }^{48}$. Toteż sformułowany przez Orsiniego-Rosenberga Program... stał się matrycą, na której oparł własny „Program badań etnologicznych...". Pytanie, czy spójność obu programów była wymogiem Komisji, czy też Komisja zaakceptowała propozycję, która wyszła od Obrębskiego, wymaga jeszcze dalszych badań.

Istotny w tym kontekście jest komentarz Olgi Linkiewicz odnoszący się do konfliktu między wykonawcami programu KNBZW, którzy reprezentowali przeciwstawne paradygmaty teoretyczno-metodologiczne:

W latach 30. [Fischer i jego uczniowie] zaczęli sobie uświadamiać, że przeciwny obóz naukowy - zwolennicy podejścia do społeczeństwa, reprezentowanego przez Znanieckiego i Malinowskiego - zdobył konkurencyjną przewage i popularność w kręgach rządowych, w szczególności u Kasprzyckiego i Paprockiego. [...] Tak więc przedstawiciele etnologii Iwowskiej publicznie głosili wierność «metodzie socjologicznej, a nawet funkcjonalnej», powołując się na prace Floriana Znanieckiego i Bronisława Malinowskiego. W rzeczywistości jednak Fischer, a zwłaszcza Falkowski, ostro krytykowali humanistyczną perspektywę Znanieckiego. [...] Jak na ironię, choć wspótzawodniczących uczonych nie łączyła choćby minimalna zgoda co do metody, w projektach sponsorowanych przez państwo lokowano ich badania blisko siebie; znacznie bliżej niż mogli przypuszczać i kiedykolwiek mogliby zaakceptować (Linkiewicz, 2016b, s. 19, 23; tłum. A.E.).

Z ustaleń Linkiewicz wynikałoby więc, że Komisja preferowała paradygmat, w którym prowadził swoje badania Obrębski, ergo na podejmowane przez nią decyzje merytorycz-

47 Jesienią 1935 r., na inauguracji seminarium narodowościowego funkcjonującego przy Instytucie, OrsiniRosenberg mówit: „[P]oza ramami tych studjów możemy być najzacieklejszymi nacjonalistami, politykami, reformatorami itd., w ramach jednak naszych studjów winniśmy tylko i wyłącznie być objektywnymi, choć wczuwającymi się w treść badanych przejawów i grup, analitykami. Nie to, co "winno być" zdaniem naszem, ale to, "co jest», co istnieje niezależnie od naszych sympatyj i antypatyj, winno nas wyłącznie zajmować" (Z Instytutu, 1935, s. 349).

48 W studium o szkole na Polesiu jako swoje kredo metodologiczne przywołał słowa Malinowskiego, które W jego przekładzie brzmią: „Ostatecznym celem, którego badacz nie powinien tracić z oczu, jest uchwycić własny punkt widzenia krajowca, jego stosunek do życia, zrozumieć własną wizję jego własnego świata" (Obrębski, 2007e, s. 335). 
ne dotyczące realizacji programu musiały w istotnym stopniu wpływać nie tyle kryteria polityczno-ideologiczne, ile te wywodzące się z najnowszych ustaleń nauk społecznych.

Program badawczy Obrębskiego, adresowany nie do odbiorcy akademickiego, lecz do urzędników państwowych, pisany formalnym i „politycznie poprawnym” językiem odbiegającym od eseistycznego stylu jego tekstów naukowych, jest dokumentem oficjalnym. Można przyjąć, że pełnił funkcję analogiczną do współczesnego wniosku grantowego. Uczony musiał więc tutaj w jakimś zakresie wychodzić naprzeciw oczekiwaniom decydentów z pola władzy. Czyniąc tak, nie wykraczał jednakże poza dyskurs naukowy. Nie przesądzał, nie oceniał; kierował się imperatywem poznawczym. Cel swoich badań formułował następująco:

[E]tnolog winien zdać sprawę z tego, czym jest współczesna rzeczywistość wsi wschodniej w dziedzinie problemów narodowościowych, jakie jest obecne oblicze narodowe ludu, jakie czynniki leżą u podstaw dokonywującej się nacjonalizacji wsi, na czem ten proces polega i w jakim kierunku zdąża (Obrębski, 1934, s. 2).

Jego perspektywa ekspercka wyrażała się z kolei w nawiązaniach do praktyki społecznej i podkreślaniu potrzeby zastosowania wyników badań:

[D]alecy jesteśmy jeszcze od momentu, gdy etnologja będzie w stanie dać na żądanie szczegółową i ścisłą odpowiedź na różne problemy życia społeczno-kulturalnego wsi. Wiele z tych problemów nie może jednak czekać [...]. [S]prawdzianem objektywizmu nauki, również jak i promotorem doskonalenia jej metod, jest zastosowalność jej dorobku w sferze zadań i problemów praktycznych. [...] [O]d pomyślnego rozwiązania tego problemu [tj. narodowościowego; A.E.] zależy, czy i w jakim stopniu uda się szerokie - indyferentne lub nawet opozycyjne - masy włościańskie na kresach wschodnich wciągnąć do czynnej, konstruktywnej kooperacji w życiu współczesnego państwa (Obrębski, 1934, s. 1-2).

Myślenie o chłopach poleskich w kategoriach potencjalnych partnerów W „Czynnej i konstruktywnej kooperacji" obywatelskiej to świadectwo emancypacyjnego i demokratycznego stanowiska Obrębskiego. Stanowiska, którego przesłanką była troska o upodmiotowienie i uobywatelnianie warstwy chłopskiej, nie zaś o jej unarodowienie w kierunku dominującej polskości. Opisując i interpretując „z punktu widzenia krajowca” proces zmiany społeczno-kulturowej w wiejskich społecznościach Polesia, przedstawiał w swoim przekonaniu obiektywne argumenty przeciwko nacjonalistycznej polityce „rozszerzania polskości poprzez ekspansję w kierunku amorficznych narodowościowo ludów kresowych", by zacytować sformułowanie Wielhorskiego (Grott, 2013, s. 95), jak również przeciwko stosowanej w jej realizacji fizycznej i symbolicznej przemocy.

\section{ETNOSOCJOLOGIA JAKO TEORETYCZNA RAMA ODNIESIENIA}

Prominentny historyk, jakim jest Timothy Snyder, nie tylko zredukował naukowy projekt Komisji NBZW do czegoś w rodzaju ofensywy wojskowej, lecz także ekspedycję Obrębskiego, wraz z badaniami prowadzonymi dla Komisji przez geografów, sprowadził do ironicznego cudzysłowu. Czy wiedział o nich cokolwiek, skoro użył sformułowania „badania "antropogeograficzne» oraz "etnosocjologiczne»" ? Tymczasem nie ma tu żadnych podstaw do ironii. Badania antropogeograficzne, a więc takie, które dziś obejmuje geografia ekonomiczno-społeczna, prowadził w ramach programu Komisji, na Łemkowszczyźnie, wybitny geograf Stanisław Leszczycki (por. Grott, 2013, s. 116-117). Badania etnosocjo- 
logiczne natomiast to kategoria zaproponowana przez Obrębskiego bezpośrednio na użytek ekspedycji poleskiej; w odnoszących się do niej programach i sprawozdaniach Komisji NBZW i Instytutu BSN systematycznie występuje właśnie ten termin. Nie tylko zresztą w tej dokumentacji. Była jeszcze jedna z pracujących dla KNBZW terenowych grup badawczych - kierowana przez Seweryna Wystoucha Grupa Wileńska - która prowadziła badania nazwane etnosocjologicznymi. Dotyczyły one "nastrojów ludności”, świadomości narodowej i stosunków narodowościowych (por. Grott, 2013, s. 117-118)49.

Zamiar prowadzenia badań na Polesiu "głównie w kierunku socjologicznym", czyli narzędziami antropologii społecznej Malinowskiego ${ }^{50}$, towarzyszył Obrębskiemu od czasów studenckich. Wraz z rozpoczęciem ekspedycji wiosną 1934 roku określił się jako etnosocjolog (bez cudzysłowu), korzystając z niemieckiego terminu Ethnosoziologie, wprowadzonego przez Richarda Thurnwalda na określenie funkcjonalizmu (por. Gingrich, 2005, s. 142). Obrębski nigdzie ściśle nie wyeksplikował swojego rozumienia etnosocjologii; definiował ją ogólnie jako "socjologię społeczeństw ludowych" i kładł nacisk na jej związek z „zagadnieniami dotyczącymi socjologii narodu” (Obrębski, 2007a, s. 276). W czasie jego studiów w Londynie wychodziło drukiem przyjmowane z powszechnym uznaniem 5-tomowe dzieło Thurnwalda Die menschliche Gesellschaft in ihren ethno-soziologischen Grundlagen (Etnosocjologiczne podstawy społeczeństw ludzkich). To wtedy musiało się W nim ugruntować zainteresowanie tą subdyscypliną antropologiii ${ }^{51}$. Już z Polesia pisał do Prüfferowej:

[S]ądzę, że zrozumiesz mój punkt widzenia, jak tylko zapoznasz się bliżej z naszą pracą. [...] Pod koniec stycznia pierwszy szkic "Zmiany kulturalnej na Polesiu» ${ }^{52}$ będzie gotowy. Będę go referować w Instytucie - mam nadzieję również przesłać jedną kopję Tobie: do krytyki i uwag; bardzo ciekaw jestem, jak ten rodzaj etnologji będzie Ci się podobał. Korybutiak, który początkowo jeżył się, w stu procentach pisze się teraz na ten kierunek i metodę, [według] których prowadzimy nasze badania. Nabiera coraz więcej rozmachu i nie wątpię, że za parę lat będzie specem etnosocjologicznym. Cieszę się z tego bardzo; czuję się teraz w swojej pracy nie tak izolowany, jak na początku (13.11.1934; MET) ${ }^{53}$.

Istnieje jeszcze argument o charakterze instytucjonalnym przemawiający za wprowadzeniem przez Obrębskiego w obieg kategorii etnosocjologia. Intensywnie wówczas w Polsce uprawianą dyscypliną, rywalizującą o prestiż i poparcie władz z innymi profesjonalizującymi się naukami społecznymi, była antropologia fizyczna, powszechnie nazy-

\section{$\cdots \cdots \cdot$}

49 Termin „badania etno-socjologiczne” funkcjonował jeszcze w okresie tużpowojennym. Tak nazywano np. finansowane przez Ministerstwo Odbudowy, a realizowane przez Polskie Towarzystwo Ludoznawcze w 1946 r. badania nad ludowym włókiennictwem na Lubelszczyźnie (nadzorowane przez Józefa Gajka, etnologa wywodzącego się z ośrodka Iwowskiego, w latach 30. zaangażowanego w projekty zamawiane przez władze), por. (PTL, sygn. 564/II). Jak z tego wynika, termin etnosocjologia musiał być dobrze zadomowiony na styku nauki i polityki.

50 W roku 1930, nie znając jeszcze Malinowskiego osobiście, pisał do niego: „[P]owziąłem decyzję poświęcić cały rok przyszły pracy terenowej w najbardziej prymitywnych okolicach Białorusi. [...] [P]ragnąłbym bardzo utrzymać kontakt z Panem Profesorem; tembardziej, że zamierzona praca pójdzie głównie w kierunku socjologicznym i oprze się na metodach Pana Profesora, znanych mi dzięki Jego pracom" (31.05.1930; LSE).

51 Prace Thurnwalda były wśród lektur Obrębskiego; we własnych pismach (choć akurat nie w poleskich) przywoływał go zarówno przed wojną, jak i po wojnie.

52 Nie znalazłam takiego tekstu w żadnym z przebadanych zasobów archiwalnych.

53 Z przedstawioną tu perspektywą Obrębskiego, jak również z teoretycznym dorobkiem jego badań poleskich współbrzmi encyklopedyczna definicja etnosocjologii: „Subdyscyplina etnologii zajmująca się badaniami procesów etnicznych i ich związkiem z przemianami społecznymi, zachodzącymi w obrębie różnych grup etnicznych; ze względu na praktyczne znaczenie etnosocjologia rozwija się głównie w krajach wieloetnicznych oraz w krajach o ludności pochodzenia imigracyjnego; powstała w latach 30. XX w. (R. Thurnwald), jej przedmiot był w dużej mierze zbieżny z programem brytyjskiej antropologii społecznej i obejmował studia nad organizacją i instytucjami społecznymi ludów niecywilizowanych i europejskich środowisk wiejskich" (https://encyklopedia.pwn.pl/haslo/etnosocjologia;3898909.html; dostęp 2.11.2018). 
wana po prostu antropologią, bez przydawki (por. Linkiewicz, 2016a). W tym kontekście termin antropologia społeczna mógł być błędnie rozumiany i źle odbierany. Etnosocjologia jako wyspecjalizowane pole w obrębie zadomowionej już w Polsce etnologii (ten termin występował w nazwach instytucji, tak samookreślali się uczeni, Malinowskiego także nazywano etnologiem) miała, dzięki składnikowi etno-, funkcję dystynktywną wobec antropologii fizycznej z jej nieskrywanym w tamtym okresie pokrewieństwem z teoriami rasistowskimi, a silny akcent położony na ukierunkowanie socjologiczne, czyli teoretyczno-metodologiczną tożsamość etnosocjologii, wskazywał jednocześnie konstytutywną odrębność od paradygmatu kulturowo-historycznego przyjmowanego przez większość ówczesnych polskich etnologów. Obrębski, określając się jako etnosocjolog, sytuował się w polu naukowym jako pionier i promotor nowatorskiego na gruncie polskim funkcjonalizmu, a zarazem na pozycji autonomicznej wobec tutejszego etnologiczno-antropologicznego mainstreamu. Dalsze badania zweryfikują hipotezę, czy to rzeczywiście za jego sprawą termin etnosocjologia wszedł w obieg wśród kreatorów polityki naukowej państwa.

\section{WYNIKI BADAŃ KONTRA LINIA POLITYCZNA WLADZY. OBRĘBSKI MIĘDZY INKLUZJĄ A EKSKLUZJĄ}

Lektura poświęconych Polesiu prac Obrębskiego, zarówno tych, które opublikował, jak i tych, które pozostawił w rękopisie, jasno pokazuje rozbieżność między formułowanymi przez niego wnioskami z badań i linią polityczną zleceniodawców. W studium o funkcjonowaniu polskiej szkoły w prawosławnych wsiach Polesia nazwat po imieniu kolonialny charakter polityki państwa polskiego w województwach wschodnich. "Nie jest to bynajmniej opis zwycięskiego pochodu cywilizacji” - pisał we wstępie do tej pracy - „prędzej kronika jej klęsk i niepowodzeń. [...] [P]ostać, jaką przybierało [to zjawisko] [...] na Polesiu, owym reliktowym rejonie tradycyjnej kultury ludowej i peryferycznym obszarze ekspansji obcej etnicznie cywilizacji narodowej, stawia je w rzędzie procesów i sytuacji, typowych dla różnych obszarów kolonialnych" (Obrębski, 2007e, s. 335). Formułował też wskazania dla praktyki społecznej, stojące $w$ jawnej sprzeczności z politycznym programem władz, np.: „Tylko zupełna zmiana funkcji społecznej szkoły, przeobrażenie jej w narzędzie walki wyzwoleńczej chłopa [...], wpajające weń chłopskie poczucie godności, świadomość własnych praw i wiarę we własne możliwości i własne siły w skali państwowej, jest w stanie nadać jej nowy sens i nowe znaczenie, zespolić z życiem wsi, z jej budzącymi się dążeniami społecznymi i narastającymi potrzebami kulturalnymi" (Obrębski, 2007e, s. 434). Z kolei w szkicu poświęconym stereotypowemu wizerunkowi Poleszuka w kulturze polskiej stwierdzit: „Poprzez obraz, który tworzymy o nim, na jego temat i jego kosztem, nie oddajemy [...] jego rzeczywistości, lecz stwarzamy wierne [...] odbicie i wizerunek siebie samych, takich jakimi współcześnie jesteśmy. Jeśli ten obraz waha się między chochołem i małpoludem - czyż Poleszuk ponosi zań odpowiedzialność?" (Obrębski, 2007c, s. 443). W powszechnym, funkcjonującym jako kulturowa oczywistość dyskursie o Polesiu i „Poleszuku" wskazywał retoryczne strategie dehumanizowania poleskich chłopów (poprzez egzotyzację czy animalizację) ${ }^{54}$, dekonstruując tym samym deprecjonujące wyobrażenia na temat białorusko-ukraińskich społeczności chłopskich, które i w środowisku nauko-

54 Ten aspekt myśli Obrębskiego - w nawiązaniu do jego sformułowania „pigmeizowanie Poleszuka” - omówiłam w: (Engelking, 2017, s. 73-80). 
wym były rozpowszechnionymi przedsądami. Dostrzeżenie w nim przez Grażynę Borkowską prekursora polskich studiów postkolonialnych (Borkowska, 2008, 2010) jest więcej niż zasadne.

Przytoczone wyżej fragmenty pochodzą z prac, które za życia Obrębskiego nie zostały opublikowane. Nie oznacza to bynajmniej, że wyrażał on niezależne sądy, pisząc do szuflady. Głosił je publicznie i ogłaszał drukiem, jak w studium Dzisiejsi ludzie Polesia, które przed publikacją (Obrębski, 1936a) przedstawił jako referat na I Zjeździe Naukowym Poświęconym Ziemiom Wschodnim we wrześniu 1936 roku. Wynikiem „dyskretnego i kunsztownego wyławiania od pozornie obojętnego i kompromisowego Poleszuka ułamków świadomości narodowej” stała się tu m.in. obserwacja, że "kulturalna asymilacja Poleszuka lub raczej upodobnienie do ogólnopolskich wzorów kulturalnych [...] nie jest bynajmniej wskaźnikiem jego asymilacji społecznej, jego wrastania w naród polski" (Obrębski, 2007a, s. 300). Opisał też społeczne i kulturowe mechanizmy antagonizmów i konfliktów polesko-polskich; analizie w kategoriach klasowych i narodowych poddał poczucie krzywdy i upokorzenia poleskich chłopów oraz kształtowanie się odnoszonego przez nich do Polaków stereotypu wroga. „W tej sytuacji wzajemnych zadrażnień" - konstatował „wizerunek środowiska polskiego kształtowany jest pod wpływem strachu, niechęci, żalu i uraz - i oczywiście jest negatywny. [...] Indywidualne krzywdy zostają [...] zgeneralizowane i uwielokrotnione, przekształcone w legendę krzywdy społecznej, lokalizowanej już nie w wąskiej sferze konfliktów chłopsko-pańskich, lecz w całej płaszczyźnie stosunków rusko-polskich" (Obrębski, 2007a, s. 298). Na te i pokrewne zjawiska wskazywał jako na „forpoczty ideologii narodowej” (Obrębski, 2007a , s. 300). Stwierdzał: „Studium Poleszuków sugeruje nam, że tym, co taka grupa etniczna pamięta nierównie silniej, są doznane w trakcie jej cywilizowania krzywdy i upokorzenia, o których znowu naród państwowy wolałby nie wiedzieć i nie pamiętać" (Obrębski, 2007a, s. 305).

Dwudniowy zjazd naukowy, o którym mowa, odbywający się na Uniwersytecie Warszawskim przy udziale prominentnych przedstawicieli świata nauki i sfer rządowych, był publicznym podsumowaniem póttorarocznych badań na Polesiu prowadzonych przez reperzentantów wielu dyscyplin pod auspicjami Komisji Naukowych Badań Ziem Wschodnich (por. Grott, 2013, s. 153-175; Linkiewicz, 2016a, s. 164; Paprocki, 1938). W żywej dyskusji, która toczyła się po trwającym godzinę wystąpieniu Obrębskiego, poruszano m.in. kwestię wypływających z jego badań wniosków dla praktyki społecznej. On sam jednakże, określając się jako teoretyk, konsekwentnie zajmował stanowisko ściśle naukowe: deklarował, że celem jego pracy jest jedynie ułatwianie „polityk[owi] i działacz[owi] społeczne[mu] [...] poznani[a] i zrozumieni[a] [...] rzeczywistości społecznej chłopa poleskiego" (Obrębski, 2007b, s. 332). „Być może należy traktować to jako próbę samoobrony człowieka nauki przed pozabadawczymi uwikłaniami. Próbę zresztą o tyle jednak nieudaną, że jego teksty wręcz nasycone są konstatacjami, które trudno określić inaczej aniżeli jako mające polityczny charakter" (Cichoracki, 2013, s. 103). Polityczny w tym sensie - rozwinęłabym myśl Cichorackiego - że z dokumentacyjną, analityczną i interpretacyjną pracą Obrębskiego ściśle wiązała się intencja zastosowania jej wyników do uobywatelniającej poleskich chłopów polityki społecznej. Obrębski-ekspert przedstawiałby się naszym oczom odmiennie, gdyby historia potoczyła się inaczej i jego ekspertyza uzyskała realny wpływ na projekty polityczne, projekty zgodne z jego systemem wartości i poglądami ${ }^{55}$.

55 Należy w tym miejscu nadmienić, że eksperckie kompetencje Obrębskiego zostały docenione w Departamencie Powierniczym ONZ, gdzie pracowat w latach 1948-1958 jako specjalista od procesów dekolonizacji. 
Przedstawiony przez Obrębskiego rozumiejący opis sytuacji społecznej Polesia, wraz z krytycznymi diagnozami, nie zmotywował rządzących do korekty polityki. Wręcz przeciwnie. „Zwraca uwagę, że miejscowa administracja, mimo znajomości wniosków z badań etnograficznych, które ogłaszane były systematycznie w dekadzie lat 30., a zwłaszcza w jej drugiej połowie, w praktyce ignorowała je. Tym samym można uznać, że w perspektywie, jaką stworzył 1939 r., przełożenie wysiłku specjalistów zajmujących się zagadnieniami poleskimi na praktykę polityczną okazało się niezauważalne" (Cichoracki, 2013, s. 113). „Zaostrzenie polityki państwa w stosunku do mniejszości narodowych z końcem lat 30. wskazuje [...], że decydenci II Rzeczypospolitej jednostronnie interpretowali wyniki prac uczonych, widząc w polonizacji Ziem Wschodnich drogę do umocnienia pozycji państwa polskiego" (Serwański, Wrzesińska, 2006, s. 88). Drogi realnej polityki i nieusłużnej nauki biegły w przeciwnych kierunkach.

Niezależnie od tego stanu rzeczy zdaje się nie ulegać wątpliwości, że prezentacja wyników ekspedycji poleskiej na poświęconym Polesiu zjeździe naukowym przyniosła Obrębskiemu uznanie w polu naukowym. Środowisko akademickie zgodnie zalegitymizowato jego pozycje jako uczonego i eksperta. Prasa donosiła: "Rektor Antoniewicz omówił poszczególne referaty, zatrzymując się nad niektórymi, jak np. referat d-ra Obrębskiego o «Dzisiejszych ludziach Polesia», podnosząc jego objektywizm, naukową metodę, żywotność poruszonych w nim zagadnień, czego dowodem była tak ożywiona dyskusja" (Lemiesz, 1936b). Zjazd odbił się szerokim echem w prasie. Przeglądając dzisiaj kilkanaście dzienników z września 1936 roku, trafiamy na notatki informacyjne i komentarze, spośród których najwięcej odnosi się do wystąpienia generała Kasprzyckiego, kierownika Biura Melioracji Polesia Stefana Rychłowskiego oraz etnosocjologa Józefa Obrębskiego. "Uczmy się wszyscy etnosocjologii!" - takim wezwaniem zakończył swój artykuł dziennikarz „Kuriera Wileńskiego" Józef Święcicki, piszący pod pseudonimem Piotr Lemiesz. Zamykając trzyodcinkowe sprawozdanie ze Zjazdu artykułem poświęconym w całości jego wystąpieniu, wskazywał - jak powiedzielibyśmy dzisiaj - na subwersyjny potencjał etnosocjologii Obrębskiego:

\footnotetext{
Wystarczy tego, cośmy tu powtórzyli za referentem i dyskutującymi [...], aby się przekonać, że etnosocjologia nie jest nauką oderwaną. Mówi ona w sposób naukowy i zrozumiały nawet dla napływowej elity to, co my ludzie miejscowi i bez tego dostatecznie rozumiemy. Wydobywa na powierzchnię tragiczne nieporozumienia, które co krok spotykamy, nieporozumienia pomiędzy nami i tymi, którzy chcą nas uszczęśliwiać wbrew naszej woli i nie chcą nas przybrać sobie do pomocy, bo nie mają zaufania, bo obawiają się obdzielić nas nadmiarem władzy. Uczmy się wszyscy etnosocjologii - może to usunie nieporozumienia (Lemiesz, 1936a).
}

Nieporozumienia jednak nabrzmiewały. Naukowa pozycja Obrębskiego w środowisku badaczy społecznych pozostała bez wpływu na politykę. I wydaje się, że inaczej być nie mogło, tym bardziej w polskich uwarunkowaniach lat trzydziestych. Można by, z punktu widzenia teorii pola Pierre'a Bourdieu, interpretować tę sytuację jako konkurencyjną koegzystencję pola władzy i pola naukowego, zogniskowaną wokół właściwych im stawek: władzy oraz uznania. Dynamika tej konkurencji zdaje się sprawiać, że każdy z podmiotów ostatecznie pozostaje przy własnej stawce: uczeni zachowują przewage merytoryczną jako eksperci, ale to aktorzy pola władzy decydują, czy wdrożą pozyskaną wiedzę do realizowanej polityki, czy też nie. Dzieje się tak, ponieważ pole naukowe należy do pól zawierających się w polu władzy i zajmujących w nim pozycję podporządkowaną.

Diagnozy Obrębskiego bardzo prędko zostały zweryfikowane pozytywnie przez dalszy przebieg wydarzeń historycznych. „Mimo szeroko zakrojonej akcji polonizacyjnej związek 
emocjonalny poleskiego chłopa z państwem polskim pod koniec lat trzydziestych XX w. był wciąż nikły" (Ablamski, 2017, s. 65). Z początkiem wojny we wrześniu 1939 roku Polesie stało się areną licznych aktów wrogości wobec Polaków: dochodziło do mordów właścicieli majątków („,polskich panów”), wycofujące się oddziały polskiego wojska i cywilni uciekinierzy przemieszczali się po terenie w uzasadnionym poczuciu zagrożenia. "Najłatwiejszy do polonizacji” „Poleszuk” potwierdził etnosocjologiczne ustalenia, że zarówno powierzchowna asymilacja kulturalna nie będąca asymilacją społeczną, jak i polski kolonializm i nacjonalizm idące w parze z wykluczaniem prawosławnych i ruskojęzycznych obywateli państwa ze społeczności ogólnonarodowej muszą nasilać wzajemną wrogość i prowadzić do otwartego konfliktu.

„Państwowo-narodowa misja cywilizacyjno-kulturalna” zakończyła się fiaskiem. Ale nieneutralny politycznie państwowy patronat nad programem naukowym, realizowanym przez wybitnego uczonego, zaowocował osiągnięciami, które wprawdzie nieprędko, lecz na trwałe weszły do nauki polskiej, ościennej i światowej.

\section{ARCHIWALIA}

AR: archiwum rodzinne Obrębskich w posiadaniu autorki; materiały warsztatowe i korespondencja Józefa Obrębskiego.

LCVA: Lietuvos centrinis valstybės archyvas; materiały Muzeum Białoruskiego.

LSE: London School of Economics Archives; korespondencja Bronisława Malinowskiego.

MET: Archiwum Muzeum Etnograficznego w Toruniu im. Marii Znamierowskiej-Prüfferowej; korespondencja Marii Znamierowskiej-Prüfferowej.

OC: "Obrebski Collection”, Special Collections and University Archives, University of Massachussetts, Amherst; spuścizna Józefa Obrębskiego.

PTL: Archiwum Polskiego Towarzystwa Ludoznawczego, Wrocław.

Yale: Yale University Archives; korespondencja Bronisława Malinowskiego.

\section{BIBLIOGRAFIA}

Ablamski, P. (2017). Kwestia narodowościowa na peryferiach Europy ŚrodkowoWschodniej: Przypadek Polesia między dwiema wojnami. Studia z Dziejów Rosji i Europy Środkowo-Wschodniej, 52(2), 57-78. https://doi.org/10.12775/SDR.2017.2.03

Benedyktowicz, Z. (2000). Józef Obrębski - identyfikacja a stereotyp. W Z. Benedyktowicz, Portrety "obcego": Od stereotypu do symbolu (ss. 19-38). Kraków: Wydawnictwo Uniwersytetu Jagiellońskiego.

Borkowska, G. (2008). Daleko od mitu: Kresy według Obrębskiego. Prace Filologiczne: Seria Literaturoznawcza, 55, 123-130.

Borkowska, G. (2010). Perspektywa postkolonialna na gruncie polskim: Pytania sceptyka. Teksty Drugie, 2010(5(125)), 40-52.

Bourdieu, P., Wacquant, L. (2001). Zaproszenie do socjologii refleksyjnej (przet. A. Sawisz). Warszawa: Oficyna Naukowa.

Cichoracki, P. (2009). Droga ku anatemie: Wacław Kostek-Biernacki (1884-1957). Warszawa: Instytut Pamięci Narodowej, Uniwersytet Wrocławski. 
Cichoracki, P. (2012). Memoriał narodowościowy wojewody poleskiego Wacława KostkaBiernackiego z 8 września 1934 r. Wrocławskie Studia Wschodnie, 16, 125-136.

Cichoracki, P. (2013). Tak zwani „tutejsi” na Polesiu jako zagadnienie polityczne w Polsce w latach 1921-1939. Sprawy Narodowościowe, 2013(42), 101-113. https://doi. org/10.11649/sn.2013.006

Cichoracki, P. (2014). Polonisation projects for Polesia and their delivery in 1921-1939. Acta Poloniae Historica, 109, 61-79. https://doi.org/10.12775/APH.2014.109.04

Engelking, A. (2001). Poleska ekspedycja etnosocjologiczna Józefa Obrębskiego w latach 1934-1937: Organizacja. Metody badań. Problematyka. Uczestnicy. Etnografia Polska, 45(1-2), 23-45.

Engelking, A. (2003). Objective observation and direct experience: Józef Obrębski's research in Macedonia, contextualizing his scientific biography (1926-1937). Ethnologia Polona, 24, 7-27.

Engelking, A. (2004). Nieznani badacze Polesia w latach trzydziestych XX wieku: Roman Chromiński, Jan Teodorowicz, Zygmunt Korybutiak: Z archiwaliów ekspedycji etnosocjologicznej Józefa Obrębskiego. W Z. Jasiewicz (Red.), Wschód w polskich badaniach etnologicznych i antropologicznych: Problematyka - badacze - znaczenie (ss. 203213). Poznań: „Biblioteka Telgte”, Komitet Nauk Etnologicznych PAN.

Engelking, A. (2005). Stanisław Dworakowski jako badacz Polesia. W L. Mróz, M. Zowczak, \& K. Waszczyńska (Red.), Regiony, granice, rubieże: Tom w darze dla Profesora Mariana Pokropka (ss. 169-192). Warszawa: DiG.

Engelking, A. (2006). Nieznany badacz Polesia i Wileńszczyzny w latach trzydziestych XX wieku: Zygmunt Jan Korybutiak (1907-1989). W A. M. Wabiszczewicz, U. A. Sieńkawiec, A. M. Swiryd, \& H. M. Iszczanka (Red.), Historyka-kulturnaja spadczyna Brescka -Pinskaha Palessia: Pamiż minutym i buduczyniaj (da 450-hoddzia h. Stolina): Zbornik materyjałau miżnarodnaj nawukowaj kanfierencyi, Stolin 28-29 wierasnia 2005 h. (U. 2, cz. 1, ss. 136-148). Brest: Wydawiectwa Bresckaha Dziarżaunaha Uniwiersyteta imia A. S. Puszkina.

Engelking, A. (2007). Polesie Józefa Obrębskiego. W J. Obrębski, Studia etnosocjologiczne: T. 1. Polesie (A. Engelking, Red.) (ss. 9-32). Warszawa: Oficyna Naukowa.

Engelking, A. (2017). „Poleszuk” nieoswojony: Wokół funkcji chłopskości w konstruowaniu polskości. Teksty Drugie, 2017(6), 68-94.

Engelking, A. (2018). Macedońskie Trobriandy: Józef Obrębski i pierwsze badania wsi europejskiej w paradygmacie funkcjonalizmu. Lud, 102. https://doi.org/10.12775/ lud102.2018.06

Etnosocjologia. (b.d.). Pobrano 2 listopada 2018, z https://encyklopedia.pwn.pl/haslo/etnosocjologia;3898909.html

Falkowski, J. (2006). Odpowiedź Jana Falkowskiego. Sprawy Narodowościowe, 2006(29), $171-172$.

Gingrich, A. (2005). The German-speaking countries. W F. Barth i in. (Red.), One discipline, four ways: British, German, French, and American anthropology (ss. 59-153). Chicago, IL: University of Chicago Press.

Grott, O. (2013). Instytut Badań Spraw Narodowościowych i Komisja Naukowych Badań Ziem Wschodnich w planowaniu polityki II Rzeczypospolitej Polskiej na Kresach Wschodnich. Kraków: Księgarnia Akademicka.

Halpern, J. M. (2002). Reflections on Jozef Obrebski's work in Macedonia from the perspective of American anthropology. Ethnologia Polona, 24, 29-41. 
Kutrzeba-Pojnarowa, A. (1979). Wkład Józefa Obrębskiego w badanie procesów etnicznych. Etnografia Polska, 23(2), 72-82.

Lemiesz, P. (1936a). Elita napływowa czyli uczmy się etnosocjologii. Kurjer Wileński, 1936(263), s. 1.

[Lemiesz, P.]. (1936b). Polesie musi być zmeliorowane: Zakończenie Zjazdu Komisji Naukowych Badań Ziem Wschodnich. Kurjer Wileński, 1936(260), s. 2.

Linkiewicz, O. (2016a). Applied modern science and the self-politicization of racial anthropology in interwar Poland. Ab Imperio, 2016(2), 153-181. https://doi.org/10.1353/ imp.2016.0001

Linkiewicz, O. (2016b). Scientific ideals and political engagement: Polish ethnology and the ,ethnic question' between the wars. Acta Poloniae-Historica, 114, 5-27. https:// doi.org/10.12775/APH.2016.114.01

Linkiewicz, O. (2019). Toward expertocracy: Scientific debates on applied knowledge in interwar Poland. W F. Cain \& B. Kleeberg (Red.), A new organon: Science studies in interwar Poland. Tübingen: Mohr Siebeck.

Łuckiewicz, A. (b.d.). Etnohraficznyja hranicy Bietarusi (Maszynopis). LCVA, Vilnius.

Nowicka, E. (2006). Obrębskiego wspólnoty wyobrażone. Sprawy Narodowościowe, 2006(29), 109-121.

Obrębski, J. (1934). Program badań etnologicznych w zakresie spraw narodowościowych w województwach wschodnich (Maszynopis). AR, Warszawa.

Obrębski, J. (1936a). Dzisiejsi ludzie Polesia. Przegląd Socjologiczny, 4(3-4), 414-446.

Obrębski, J. (1936b). Problem etniczny Polesia. Sprawy Narodowościowe, 10(1-2), 1-23.

Obrębski, J. (1936c). Problem grup etnicznych w etnologii i jego socjologiczne ujęcie. Przegląd Socjologiczny, 4(1-2), 177-195.

Obrębski, J. (1936d). Statyczne i dynamiczne podejście w badaniach narodowościowych. Sprawy Narodowościowe, 10(6), 585-600.

Obrębski, J. (1939). J. Czekanowski, Wstęp w: Człowiek - jego rasy i życie. Wydawnictwo zbiorowe ilustrowane w opracowaniu prof dra J. Czekanowskiego, dra S. Klimka, dra J. Mydlarskiego, prof. dra T. Sulimirskiego, dra S. Żejmo-Żejmisa, Warszawa 1938. Przegląd Socjologiczny, 7(1-2), 353-360.

Obrębski, J. (2007a). Dzisiejsi ludzie Polesia. W J. Obrębski, Studia etnosocjologiczne: T. 1. Polesie (A. Engelking, Red.) (ss. 276-318). Warszawa: Oficyna Naukowa.

Obrębski, J. (2007b). Dyskusja po referacie Józefa Obrębskiego "Dzisiejsi ludzie Polesia". W J. Obrębski, Studia etnosocjologiczne: T. 1. Polesie (A. Engelking, Red.) (ss. 319334). Warszawa: Oficyna Naukowa.

Obrębski, J. (2007c). Legenda leśnych ludzi. W J. Obrębski, Studia etnosocjologiczne: T. 1. Polesie (A. Engelking, Red.) (ss. 435-443). Warszawa: Oficyna Naukowa.

Obrębski, J. (2007d). Lud bez ojczyzny. W J. Obrębski, Studia etnosocjologiczne: T. 1. Polesie (A. Engelking, Red.) (ss. 186-275). Warszawa: Oficyna Naukowa.

Obrębski, J. (2007e). Pańska szkoła i mużyckie dzieci. W J. Obrębski, Studia etnosocjologiczne: T. 1. Polesie (A. Engelking, Red.) (ss. 335-434). Warszawa: Oficyna Naukowa.

Orsini-Rosenberg, S. (1929). Program badań socjologicznych $w$ zakresie spotecznego podłoża życia gospodarczego w województwach wschodnich Rzeczypospolitej Polskiej. Poznań: Polski Instytut Socjologiczny.

Orsini-Rosenberg, S. (1930). Program badań socjologicznych w zakresie zagadnień narodowościowych w województwach wschodnich Rzeczypospolitej Polskiej. Warszawa: Instytut Badań Spraw Narodowościowych. 
Paprocki, S. J. (Red.). (1938). I Zjazd Naukowy Poświęcony Ziemiom Wschodnim w Warszawie 20 i 21 września 1936 r. Polesie (Sprawozdanie i dyskusje). Warszawa: Komisja Naukowych Badań Ziem Wschodnich.

Pieciukiewicz, M. (2005). Listy (1956-1982) (H. Głogowska \& W. Choruży, Red.). Białystok: Białoruskie Towarzystwo Historyczne.

Poczobut, A. (2013, październik 7). Siatka statystyka. Wyborcza.pl, Alehistoria.pl. Pobrano 12 listopada 2018, z http://wyborcza.pl/alehistoria/1,121681,14719074,Siatka_statystyka.html.

Risteski, L. S. (2011). Josef Obrebski's anthropological research on Macedonia. Etnoantropoloshki problemi, 6(4), 837-858.

Serwański, J., \& Wrzesińska, K. (2006). Józef Obrębski w Instytucie Badań Spraw Narodowościowych w latach 1934-39. Sprawy Narodowościowe, 2006(29), 81-89.

Snyder, T. (2008). Tajna wojna: Henryk Józewski i polsko-sowiecka rozgrywka o Ukraine (B. Pietrzyk, Tłum.). Kraków: Społeczny Instytut Wydawniczy Znak.

Stach, S. (2016). The Institute for Nationality Research (1921-1939) - A think tank for minority politics in Poland? W Y. Kleinmann, S. Stach, \& T. L. Wilson (Red.), Religion in the mirror of law: Eastern European perspectives from the early modern period to 1939 (ss. 149-179). Frankfurt am Main: Vittorio Klostermann.

Z Instytutu Badań Spraw Narodowościowych. (1935). Sprawy Narodowościowe, 9(3-4), 346-349. 